\title{
Multiannual soil mulching in agriculture: analysis of biogeochemical soil processes under plastic and straw mulches in a 3-year field study in strawberry cultivation
}

\author{
Maximilian Meyer ${ }^{1}\left[\right.$ Dörte Diehl ${ }^{1} \cdot$ Gabriele Ellen Schaumann ${ }^{1} \cdot$ Katherine Muñoz $^{2}$
}

Received: 23 March 2021 / Accepted: 24 July 2021 / Published online: 4 August 2021

(c) The Author(s) 2021

\begin{abstract}
Purpose The application of plastic mulching differs globally as well as climate, soils, crops, and agricultural practices, making it difficult to generalize the reported impacts on soil. Because literature is scarce about the influence of plastic mulching on soil under temperate, humid climate, the objective of this study was to understand how multiannual plastic mulching influences central soil parameters and processes under Central European cultivation conditions to evaluate its impact on soil quality in the long term.

Materials and methods Central soil parameters and processes like leaching, aggregation, soil organic matter (SOM), and microbial biomass were investigated in a strawberry cultivation in Southwestern Germany. The field experiment compared a plastic-covered ridge-furrow system with subsurface drip irrigation (PC) to the same system with straw coverage (SC) in three soil layers $(0-10,10-30$, and $30-60 \mathrm{~cm})$ at seven dates within a 3-year period. Soil analyses comprised soil temperature and moisture, $\mathrm{pH}$, bulk density, water-stable aggregates, soil organic carbon, dissolved organic carbon, and microbial biomass carbon and nitrogen.

Results Rainfall infiltration impeded by PC reduces soil moisture but neither reduces leaching nor promotes (macro-)aggregate formation or stability; however, it maintains a loose and friable soil structure in surface soil $(0-5 \mathrm{~cm})$, compared to SC. PC promotes SOM accumulation and shifted SOM composition to a more hardly degradable SOM, especially below the topsoil $(10-60 \mathrm{~cm})$. Furthermore, PC revealed no indications of an increased microbial biomass or activity accompanied with an enhanced SOM decomposition due to the shifted microclimate. The seasonal, time- and depth-dependent effects, observed in some parameters, emphasize the importance to include them in future studies for a more holistic process understanding. Conclusion Our study showed no indications that multiannual plastic mulching influences soil quality within the 3 years of this study. Further research is advisable to support our findings on a larger scale and longer time periods and across various soil and crop types.
\end{abstract}

Keywords Drip-irrigated ridge-furrow mulching $\cdot$ Humid region $\cdot$ Soil structure $\cdot$ Aggregate stability $\cdot$ Soil organic matter · Soil microbial biomass

Responsible editor: Caixian Tang

Gabriele Ellen Schaumann

schaumann@uni-landau.de

1 Group of Environmental and Soil Chemistry, iES Landau, Institute for Environmental Sciences, University of KoblenzLandau, Landau, Germany

2 Group of Organic and Ecological Chemistry, iES Landau, Institute for Environmental Sciences, University of Koblenz-Landau, Landau, Germany

\begin{tabular}{|c|c|}
\hline \multicolumn{2}{|c|}{ Abbreviations } \\
\hline SOM & Soil organic matter \\
\hline PC & $\begin{array}{l}\text { Plastic-covered ridge-furrow system with } \\
\text { subsurface drip irrigation }\end{array}$ \\
\hline $\mathrm{SC}$ & $\begin{array}{l}\text { Straw-covered ridge-furrow system with sub- } \\
\text { surface drip irrigation }\end{array}$ \\
\hline $\mathrm{CEC}$ & Cation-exchange capacity \\
\hline${ }^{1} \mathrm{H}-\mathrm{NMR}$ & Proton nuclear magnetic resonance \\
\hline SOC & Soil organic carbon \\
\hline $\mathrm{C}: \mathrm{N}$ ratio & Carbon-to-nitrogen ratio \\
\hline MBC & Microbial biomass carbon \\
\hline
\end{tabular}


MBN Microbial biomass nitrogen

DOC Dissolved organic carbon

\section{Introduction}

During the past decades, plastic mulching has become a worldwide practice, and further expansion is forecasted for the next years (Sintim and Flury 2017; Transparency Market Research 2020). Plastic mulching is applied for a variety of purposes; all aim to improve growth and harvest conditions and thus agronomic productivity (reviewed in Gan et al. 2013; Steinmetz et al. 2016). Different materials are used to produce plastic mulches, which are applied in various thicknesses, mulching arrangements, and periods (Kasirajan and Ngouajio 2012; Liu et al. 2014; Zhao et al. 2018) to various crops, soil types, and climatic conditions. Application and purposes of plastic mulching can differ globally: In China, with 20 million ha of plastic-covered farmland and globally the largest user of plastic mulches (Liu et al. 2014; Mordor Intelligence 2020), mainly film thicknesses $<0.008 \mathrm{~mm}$ are used, whereas in Europe and the USA often film thicknesses $\geq 0.020 \mathrm{~mm}$ are used (Liu et al. 2014; Ingman et al. 2015). In China, plastic mulching is mainly used to improve water use efficiency to ensure agronomic productivity under water-scarce conditions, as large parts of the farmland are located in arid and semiarid regions (Deng et al. 2006; Han et al. 2014; Zhang et al. 2018; Gao et al. 2019). Conversely, in Europe, plastic mulching is mainly used to improve product quality and to promote earliness or extend harvest periods (Scarascia-Mugnozza et al. 2011; Neri et al. 2012) and is hence often used for premium and seasonal products, such as strawberries, asparagus, and other vegetables (Scarascia-Mugnozza et al. 2011; Steinmetz et al. 2016).

Most current research and scientific literature on plastic mulching and its impacts on soil is based in China, whereas in Europe, scientific literature and research is scarce on this topic, despite of its increasing application (Mordor Intelligence 2020). Since application of plastic mulching can differ globally, as exemplarily described above, as well as climate, soils, crops, and agricultural practices (Farmer et al. 2017; Ma et al. 2018), it is difficult to extrapolate the reported impacts on soil to European cultivation condition. Furthermore, Steinmetz et al. (2016) pointed out that most recent studies focused on individual effects of plastic mulches, particularly on their short-term agronomic benefits, whereas a substantial process understanding of its impact on key soil parameters and processes is still missing but necessary to evaluate the impact of plastic mulching on soil quality in the long term. Additionally, less literature is available on the influence of plastic mulching on soil below the topsoil layer $(0-10 \mathrm{~cm})$ and over the temporal course of a multiannual application, typical in, e.g., strawberry and asparagus cultivation (Steinmetz et al. 2016).

A common plastic mulching application, e.g., in strawberry cultivation, is to cover the ridges of a ridge-furrow system with a black plastic film (mostly black polyethylene), often combined with subsurface drip irrigation (Neri et al. 2012; Poling 2016). The optical properties and the impermeability (physical barrier) of the plastic film influence heat transfer and impede gas and mass exchange between soil surface and surroundings (Ham et al. 1993; Ham and Kluitenberg 1994; Khan et al. 2000). This increases soil temperature; reduces evaporation, rainfall infiltration, and entry of aboveground biomass; suppresses weed growth; and decreases soil erosion by wind and water (reviewed in Gan et al. 2013; Steinmetz et al. 2016). This in turn can impact on biogeochemical soil processes such as aggregation, leaching, soil organic matter (SOM) decomposition, and microbial biomass growth and activity.

The objective of this study was to provide information on the influence of multiannual plastic mulching application on biogeochemical soil processes, governing SOM quality, soil structure, and microbial biomass, under humid Central European cultivation conditions to better estimate the plastic mulching impact on soil quality.

Rainfall increases soil moisture and can induce seepage water flows after infiltration, which can increase nutrient leaching (Cameron et al. 2013). Furthermore, rainfalls can cause aggregate slaking and dispersion at the soil surface, resulting in crusted soil with a higher density and erodibility and lower aeration (Bronick and Lal 2005; Bing So 2006). Consequently, we hypothesized the following: (1) The water-impermeable PC reduces leaching due to impeded rainfall infiltration and hence impeded seepage water flow during rainfall events. (2) PC maintains a loose and friable soil structure in the topsoil, because PC prevents aggregate slaking and dispersion on the soil surface during rainfall and thus crust formation, soil silting, and compaction.

Soil temperature and moisture influence the shoot and root growth of plants (Kumar and Dey 2011; Gan et al. 2013) and growth and activity of microorganisms (Coûteaux et al. 1995; Pietikåinen et al. 2005). Microbial biomass, SOM, roots, and soil moisture influence aggregate formation and stability (Bronick and Lal 2005). Thus, the third hypothesis was as follows: (3) The elevated soil temperature and moisture under PC promotes root and microbial biomass growth and leads to increasing macroaggregate formation and stability. Plant growth affects SOM inputs into soil (Grego and Lagomarsino 2008; Jackson et al. 2017), whereas microbial biomass and activity correlate positively with SOM decomposition (von Lützow and Kögel-Knabner 2009; Stockmann et al. 2013). SOM input and decomposition govern the quantity and composition of SOM (von Lützow et al. 2006). Derived from this, we hypothesized 
that (4) PC reduces SOM due to an impeded entry of aboveground biomass into soil and enhanced SOM decomposition, induced by the larger microbial biomass under PC. (5) Furthermore, $\mathrm{PC}$ reduces the fresh and fast-mineralizable SOM and thus shifts SOM composition towards an older, hardly degradable SOM.

In order to test this hypotheses, the respective soil processes were investigated in a plastic-covered ridge-furrow system with subsurface drip irrigation (PC) in comparison to the same system with straw coverage (SC) in three soil layers $(0-10,10-30$, and 30-60 cm) at seven dates within a 3-year period of strawberry cultivation in Southwestern Germany. With this experiment design, an additional focus was set on how the plastic coverage influences soil in a temporal course and in two soil layers below the topsoil $(0-10 \mathrm{~cm})$.

\section{Material and methods}

\subsection{Site description and field establishment}

The sampling site was a commercial strawberry field in Southwestern Germany $\left(49^{\circ} 11^{\prime} \mathrm{N}, 8^{\circ} 10^{\prime} \mathrm{E}, 130 \mathrm{~m}\right.$ asl), located in a temperate, humid climate with an annual average rainfall of $643 \mathrm{~mm}$ year $^{-1}$ (weather station of LandauWollmesheim, Agrarmeteorologie Rheinland-Pfalz). According to FAO soil classification, the soil type was classified as a silt loam (Anthrosol) (IUSS Working Group WRB 2015) and the soil texture consisted of $7 \pm 2 \%$ sand, $83 \pm 5 \%$ silt, and $10 \pm 3 \%$ clay in the $0-60-\mathrm{cm}$ soil layer. The sampling field was cultivated with winter wheat in the previous season and had neither been cultivated with strawberries nor been mulched with plastic or straw in recent years. After tillage and fertilization (MALTaflor ${ }^{\circledR}$ and NPK $(\mathrm{Mg})$ fertilizer), a raster sampling was conducted on the field (May 2016), which identified no significant gradients or inhomogeneities of soil properties that may interfere with the experiment design. A ridge-furrow system was established in the field (late June 2016) with subsurface drip irrigation and black plastic-covered ridges (polyethylene, $50 \mu \mathrm{m}$ ) and bare furrows. Strawberries (Fragaria $\times$ ananassa, 'Malwina') were planted as bare-root plants in mid-July 2016 at the ridges in double rows with a $40-\mathrm{cm}$ distance between plants (8 plants per $\mathrm{m}^{2}$ ). A straw coverage (wheat straw) was applied to the furrows in April 2017 and was renewed every year. Further information about the sampling site can be found in Meyer et al. (2020).

\subsection{Experimental design and soil sampling}

In short, a semi-controlled field experiment was designed that reflected current agricultural practice while enabling us to study soil processes in a homogeneous soil type and avoiding masking of treatment effects by landscape variation and edge effects. Two treatment areas were chosen $(21 \times 10 \mathrm{~m})$, respectively, one with plastic-covered and one with straw-covered ridges (PC and SC), in which respectively five sampling plots $(10 \times 1.5 \mathrm{~m})$ were randomly chosen for soil sampling: PC $(n=5)$ and SC $(n=5)$. To establish the SC treatment area, the plastic film was manually removed from the ridges immediately after field setup (July 2016). As usual in strawberry cultivation, the ridges were covered with wheat straw before the first harvest (April 2017) and the straw cover was yearly renewed.

Ten soil samplings were conducted during a 3-year period of strawberry cultivation from 2016 to 2019 (SI Fig. 1): During the establishment period of strawberries, three samplings in 2-month intervals were conducted after strawberry plantation from late July to late November in 2016 (T0-T2) to identify a potential short-term impact of PC on soil parameters and processes after field setup and strawberry plantation (results described in Meyer et al. (2020)). The results of T0 (25 July 2016) and T1 (26 September 2016) are presented here again to describe the initial field conditions and to draw conclusions over the full 3 -year investigation period. For the remaining investigation period, five samplings were conducted in larger time intervals ( $\geq 6$ months) on 25 April 2017 (T3), 9 October 2017 (T6), 3 May 2018 (T7), 11 October 2018 (T8), and 23 July 2019 (T9). In order to give a complete overview over the samplings conducted in the 3-year field study, two further samplings have to be mentioned here: They were conducted on 19 June (T4) and 18 July (T5) in 2017 after fungicide application to estimate the influence of both coverage types (plastic vs. straw) on fungicide residues in soil and their impact on mycotoxin occurrence, microbial biomass, and SOM decomposition (results described in Meyer et al. (2021)). Besides coverage type, the agricultural practice was identical in both treatments: Subsurface drip irrigation (three emitters per meter) was applied from March until September each year depending on weather conditions for 3-4 $\mathrm{h}$ a day (7-11 $\mathrm{L}$ water per meter). The field was weekly fertilized with a mineral fertilizer $(15 \mathrm{~kg} \mathrm{~N}$, $5 \mathrm{~kg} \mathrm{P}, 30 \mathrm{~kg} \mathrm{~K}, 2 \mathrm{~kg} \mathrm{Mg}$ ) via drip irrigation during an 8 -week period from March to May each year. The fungicides Switch ${ }^{\circledR}$ (37.5\% cyprodinil and $25 \%$ fludioxonil) and Teldor ${ }^{\circledR}$ (50\% fenhexamid) were yearly applied during strawberry bloom with an application rate of 1 and $2 \mathrm{~kg} \mathrm{ha}^{-1}$, respectively.

Composite soil samples (five single cores) were taken in the ridges of each sampling plot in the surface, root and subsoil layer $(0-10,10-30$, and $30-60 \mathrm{~cm})$ at each sampling date. Soil samples were collected with stainless steel soil sampling rings $(0-10 \mathrm{~cm})$ and a boring $\operatorname{rod}(>10 \mathrm{~cm})$. Further information about experimental design and soil sampling can be found in Meyer et al. (2020). 
Besides the pore size distribution, the same soil parameters were determined in this study as in Meyer et al. (2020) with identical methods. Therefore, these methods are subsequently only briefly outlined.

\subsection{Soil temperature and moisture}

A field measuring station (ecoTech ${ }^{\circledR}$, Bonn, Germany) recorded hourly soil temperature and moisture in both treatment areas at the 5-, 15-, and 35-cm soil depths, according to the investigated soil layers in the field experiment. Air temperature and precipitation data were received from the weather station of Landau-Wollmesheim (Agrarmeteorologie, Rheinland-Pfalz). The differences in soil temperature and moisture between SC and PC were calculated for each soil depth based on daily means. The data were smoothened by calculating for each day a 60 -day mean (30 days before and after this day).

\subsection{Soil physicochemical parameters}

The cation-exchange capacity (CEC) was determined at the first (T0) and last sampling (T9), according to DIN ISO 11,260:1997-05. In short, field-fresh soil was threefold extracted with $0.1 \mathrm{M} \mathrm{BaCl}_{2}$ solution and subsequently with $0.02 \mathrm{M} \mathrm{MgSO}_{4}$ solution. Both extracts were analyzed with inductively coupled plasma-optical emission spectrometry (Agilent 720 Series, Thermo Fisher Scientific, Karlsruhe, Germany). Soil pH in $0.01 \mathrm{M} \mathrm{CaCl}_{2}$ solution and electrical conductivity in deionized water were determined with airdried soil, based on DIN EN 15,933:2012-11 and DIN CEN/ TS 15,937:2013-08, respectively. Total $\mathrm{N}$ was measured in milled, oven-dried soil with a CHNS analyzer (vario MicroCUBE, Elementar Analysensysteme GmbH, Langenselbold, Germany).

\subsection{Soil structure indicators}

Bulk density, pore size distribution, and water-stable aggregates are interconnected soil structure parameters, which can be used to assess the influence of agricultural practices on soil structural stability, aeration, waterholding capacity, and water movement (Bronick and Lal 2005; Lal 2006). The determination of the bulk density and the pore size distribution was restricted to the 0-5$\mathrm{cm}$ soil layer, since the impact of coverage type was expected mainly in the surface soil. The dry bulk density was determined gravimetrically, according to DIN ISO 11,272:2014-06. The pore size distribution was determined with the method described in Meyer et al. (2018). In brief, soil cores were sampled with plastic rings $(d=3.64 \mathrm{~cm}, h=5 \mathrm{~cm})$ in triplicates at one sampling plot in both treatment areas, respectively. Samples were completely saturated with water, and subsequently, a matric potential of $-0.3 \mathrm{kPa}$ was adjusted with a sandbox (08.01 sandbox, Eijkelkamp, Zeitz, Germany). Samples were weighted at matric potential of $-0.3 \mathrm{kPa}$ and subsequently measured with proton nuclear magnetic resonance $\left({ }^{1} \mathrm{H}-\mathrm{NMR}\right)$ relaxometry, using a Bruker Minispec MQ, version 2.2 (Bruker BioSpin, Rheinstetten, Germany). After ${ }^{1} \mathrm{H}-\mathrm{NMR}$ measurement, a replicate was centrifuged for 20 min at $2000 \mathrm{~g}$ with a Universal 320 centrifuge (Hettich Lab Technology, Tuttlingen, Germany) to remove bulk solution, using centrifuge tubes with $2-\mu \mathrm{m}$ filter inserts. The bulk solution was afterwards measured with ${ }^{1} \mathrm{H}-\mathrm{NMR}$ relaxometry to receive the bulk relaxation time. Two replicates were dried at $105{ }^{\circ} \mathrm{C}$ to determine the gravimetrical water content at matric potential $-0.3 \mathrm{kPa}$. The ${ }^{1} \mathrm{H}-\mathrm{NMR}$ device measured the transverse relaxation time with a Carr-Purcell-Meiboom-Gill pulse sequence at a magnetic field strength of $0.176 \mathrm{~T}$ and the following instrument settings: 256 scans were conducted and the echo time was set to $300 \mu$ s. Gain was adjusted to $80-90 \%$ signal intensity. The repetition time and the number of $180^{\circ}$ pulses were set individually such that complete magnetization decay of the prior measurement was enabled. The Butler, Reeds, and Dawson algorithm (Butler et al. 1981) was used in MATLAB 7.7.0 (R2008b) to convert ${ }^{1} \mathrm{H}-\mathrm{NMR}$ data into relaxation time distributions. Each relaxation time constant of the relaxation time distributions was bulk-corrected with the bulk relaxation time and subsequently transformed with the "common calibration curve" into pore sizes. The amplitudes associated with the relaxation time constants were transformed with the gravimetric water content of a sample into pore volume (the sum of all amplitudes is equal to the gravimetric water content of a sample). The volumes of the macropore, medium pore, and micropore domains $(>10,0.2-10$, and $<0.2 \mu \mathrm{m}$ ) were calculated from the pore size distributions (Blume et al. 2016) by cumulating the volumes of the single pore sizes belonging to the pore range of the respective pore domains. The water-stable aggregates (soil aggregates $>0.2 \mathrm{~mm}$ ) of the 1-2-mm aggregate fraction was determined by the wetsieving procedure (Buchmann et al. 2015). The 1-2-mm aggregate fraction was separated from air-dried, sieved $(<2-\mathrm{mm})$ soil samples with a $1-\mathrm{mm}$ sieve, and its weight percent of the total soil fraction was determined.

\subsection{Characterization of SOM}

We used the soil organic carbon (SOC) to quantify SOM and the $\mathrm{C}: \mathrm{N}$ ratio as an indicator for degradability and transformation velocity of SOM (Kindler et al. 2011). Soil microbial carbon (MBC) and nitrogen (MBN) were used to quantify soil microbial biomass. The MBC:MBN 
ratio was used to estimate the microbial community composition (Moore et al. 2000). Because of their rapid turnover rates, $\mathrm{MBC}$ and dissolved organic carbon (DOC) can be used as indicators for changes in SOM due to management practices (Haynes 2005). In order to identify potential changes in different SOM pools, the SOM was separated depending on density into free, aggregate-occluded, and mineral-associated SOM fraction. According to their turnover rates, these SOM fractions are associated with the active, slow (or intermediate), and passive (or inert) SOM pool, respectively (von Lützow et al. 2007).

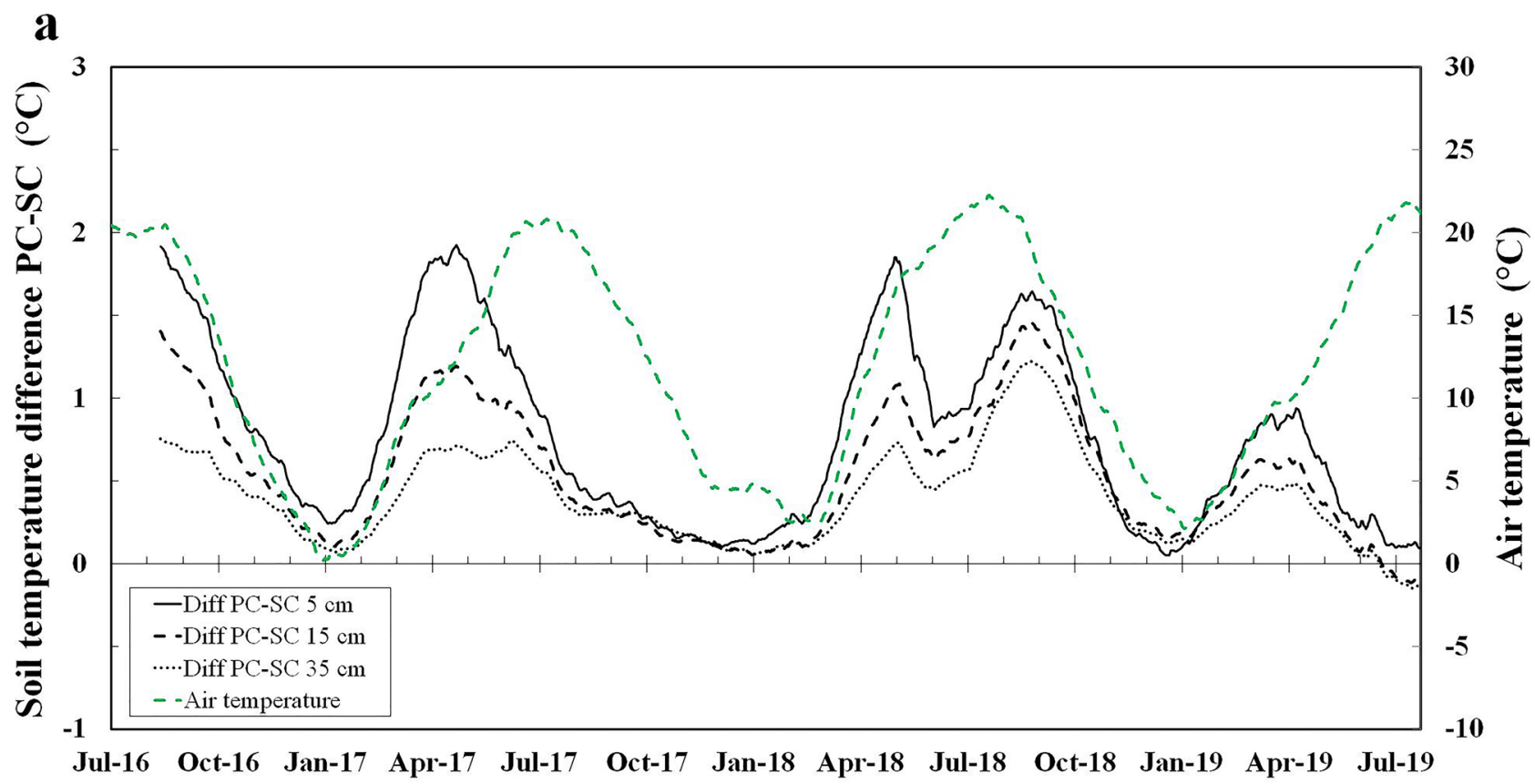

b

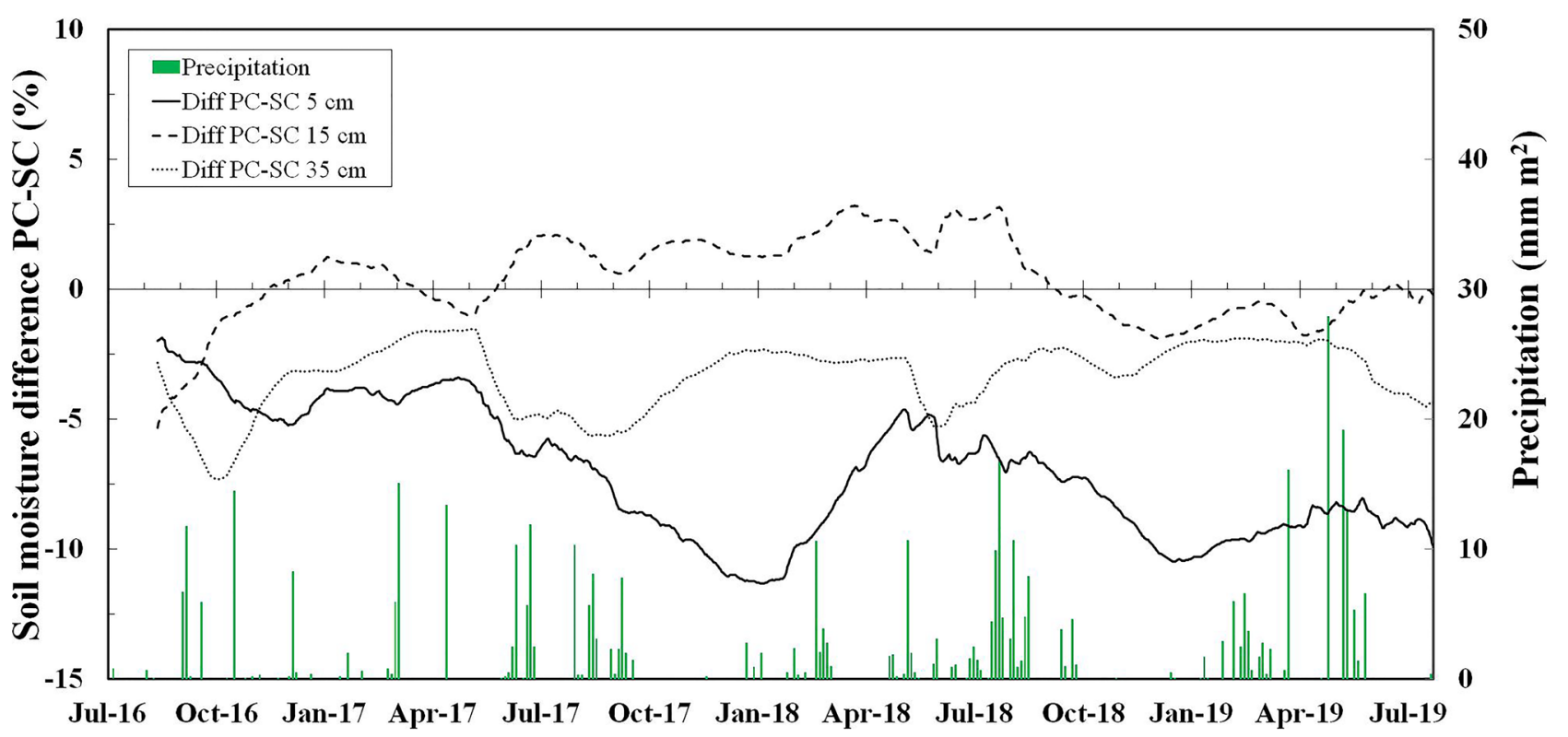

Fig. 1 Soil temperature and moisture of the 3-year field experiment in strawberry cultivation (Fragaria $\times$ ananassa, 'Malwina'). a Smoothened soil temperature differences, based on daily means, between plastic coverage (PC) and straw coverage (SC) measured at 5-, 15-, and 35-cm soil depths and daily mean air temperature measured $2 \mathrm{~m}$ above ground. b Smoothened soil moisture differences, based on daily means, between plastic coverage (PC) and straw coverage (SC) measured at 5-, 15-, and 35-cm soil depths and daily precipitation 


\subsubsection{Analysis of SOC and DOC}

The SOC was measured in accordance with Harris et al. (2001). After carbonate removal with $\mathrm{HCl}$ fumigation, the oven-dried soil samples were analyzed for carbon content with a CHNS analyzer (vario MicroCUBE, Elementar Analysensysteme GmbH, Langenselbold, Germany). In accordance with DIN EN 1484:1997-05, the DOC was measured in filtrated soil extracts $(0.45 \mu \mathrm{m})$ from field-fresh soil with a TOC analyzer (multiNC 2011S, Analytik Jena AG, Jena, Germany).

\subsubsection{Separation of SOM into free, aggregate-occluded, and mineral-associated SOM fractions by density fractionation}

The density fractionation was conducted through an adapted method, principally based on the methods described by Cerli et al. (2012) and Ontl et al. (2015): In brief, air-dried, sieved soil $(2 \mathrm{~mm})$ was carefully extracted with sodium polytungstate solution $\left(1.6 \mathrm{~g} \mathrm{~cm}^{-3}\right)$. The centrifuged supernatant was filtered $(20 \mu \mathrm{m})$, and filter residues were quantified gravimetrically (free SOM) after cleaning (deionized water) and drying $\left(60^{\circ} \mathrm{C}\right)$. In a second step, soil was re-suspended with sodium polytungstate solution and treated ultrasonically $\left(350 \mathrm{~J} \mathrm{~mL}^{-1}\right)$ for aggregate disruption. Again, the centrifuged supernatant was filtered $(20 \mu \mathrm{m})$ and filter residues were quantified gravimetrically (aggregate-occluded SOM). The mineral-associated SOM fraction was obtained by subtracting free and aggregate-occluded SOM from the total SOM. Total SOM was obtained by multiplying the SOC values by a factor of 2 (Blume et al. 2016).

\subsubsection{Analysis of MBC and MBN}

The MBC and MBN were determined by the chloroformfumigation method (Vance et al. 1987; Blume 2000): Respectively, a chloroform-fumigated and a non-fumigated sample of field-fresh soil were extracted with $0.5 \mathrm{M} \mathrm{K}_{2} \mathrm{SO}_{4}$ solution. The filtered soil extracts were analyzed for carbon content with a TOC analyzer (multiNC 2011S, Analytik Jena AG, Jena, Germany) and for ninhydrin-reactive nitrogen (Joergensen and Brookes 1990) with a photometer (Specord50, Analytik Jena GmbH, Jena, Germany).

\subsection{Statistical analyses}

The correlation of two variables was estimated with Pearson's correlation coefficient or Spearman's rho if data were not normally distributed. The normality distribution of data was examined graphically with histograms and quantile-quantile plots. Mixed factorial ANOVAs with coverage time and soil depth as repeated factors and treatment
Fig. 2 Physicochemical soil properties. a pH (in $0.01 \mathrm{M} \mathrm{CaCl}_{2}$ ) determined in the 0-10-, 10-30-, and 30-60-cm soil layers under plastic coverage (PC) and straw coverage (SC) at seven dates within the 3-year field experiment in strawberry cultivation (Fragaria $\times$ ananassa, 'Malwina'), respectively, shown as mean with standard error $(n=5)$. b Electrical conductivity. $\mathbf{c}$ Total nitrogen

as fixed factor were applied to determine significant differences between means. If significant interaction effects were determined, additional ANOVAs, with least significance distance testing as post hoc test, were applied to locate significant differences. Variance homogeneity was confirmed with Levene's test. Differences were reported as statistically significant if the probability of error was $<0.05$. All statistical analyses were done with IBM SPSS Statistics 25.

\section{Results}

\subsection{Soil temperature and moisture}

Soil temperature differences between PC and SC (Fig. 1a, SI Fig. 2) showed that soil temperature was higher under PC during the 3-year sampling period. Maxima of up to $2{ }^{\circ} \mathrm{C}$ higher soil temperature under PC were yearly found in spring (March-June) and additionally in late summer and autumn (August-October) in 2016 and 2018. During these periods, soil depth had a clear effect on soil temperature difference (differences of $>0.5^{\circ} \mathrm{C}$ between soil depths), which decreased with increasing soil depth. No or only small differences $\left(<0.2{ }^{\circ} \mathrm{C}\right)$ were observed between soil depths in the remaining autumn and winter periods. The hourly recorded data revealed up to $6.5^{\circ} \mathrm{C}$ higher soil temperatures under PC than under SC at 5-cm soil depth during midday on sunny days in the summer season (data not shown).

The differences in soil moisture between PC and SC (Fig. 1b, SI Fig. 3) demonstrated that soil moisture under SC was about 5-10 and 2-5\% higher at the 5- and $35-\mathrm{cm}$ soil depths, respectively (with maxima of $>10 \%$ in winter 2018 and 2019 at $5 \mathrm{~cm}$ and of $\geq 5 \%$ in summer and autumn at $35-\mathrm{cm}$ depth). In contrast, the $15-\mathrm{cm}$ soil depth showed partly higher soil moisture under PC (mainly from June 2017 to September 2018) and, generally, the smallest differences in soil moisture between treatments (mostly $<2 \%$ ). The 20 largest daily rainfall events during the sampling period ( 15.1 to $39.8 \mathrm{~mm}$ ) showed that the increase in soil moisture after rainfalls was clearly lower and mostly delayed at 5-cm soil depth under PC in comparison to SC (SI Fig. 4a-p). In contrast, soil moisture increases were greater after rainfalls under PC than under $\mathrm{SC}$ at the $35-\mathrm{cm}$ depth and partly at the $15-\mathrm{cm}$ soil depth. Generally, the increase in soil moisture after rainfalls decreased and was temporally delayed with increasing 


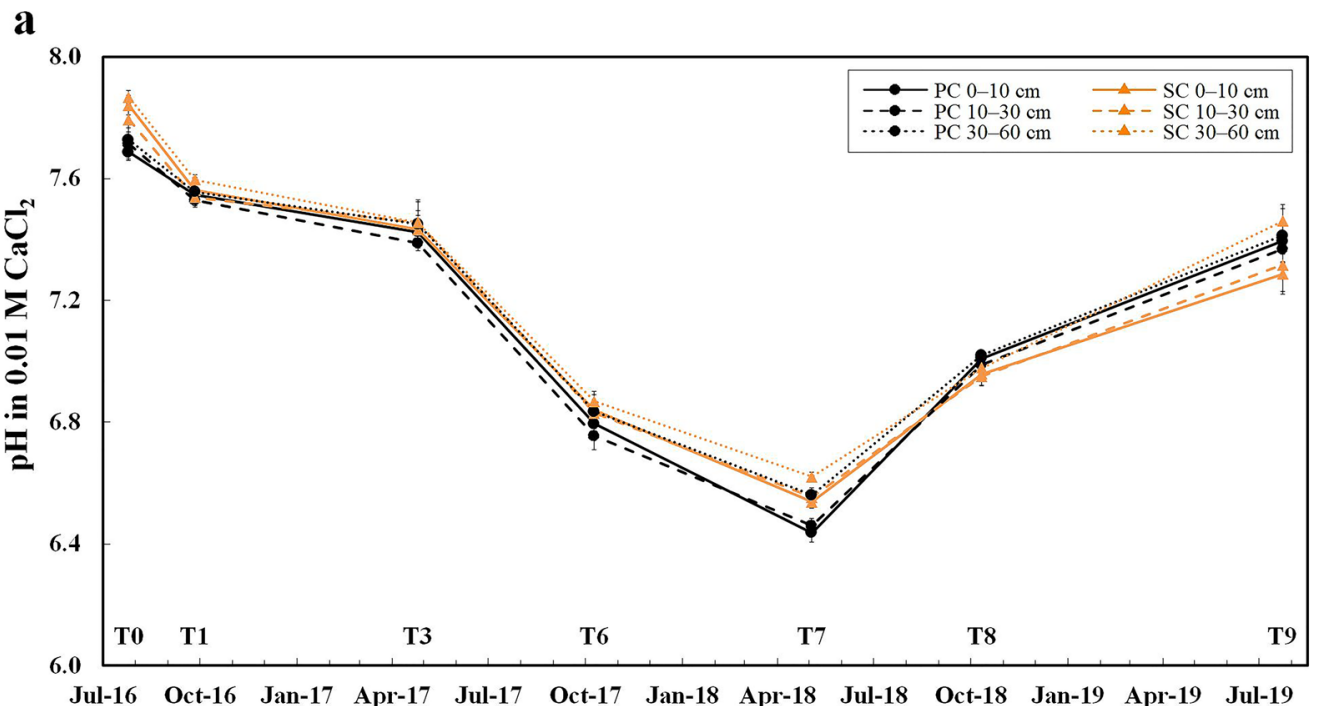

b
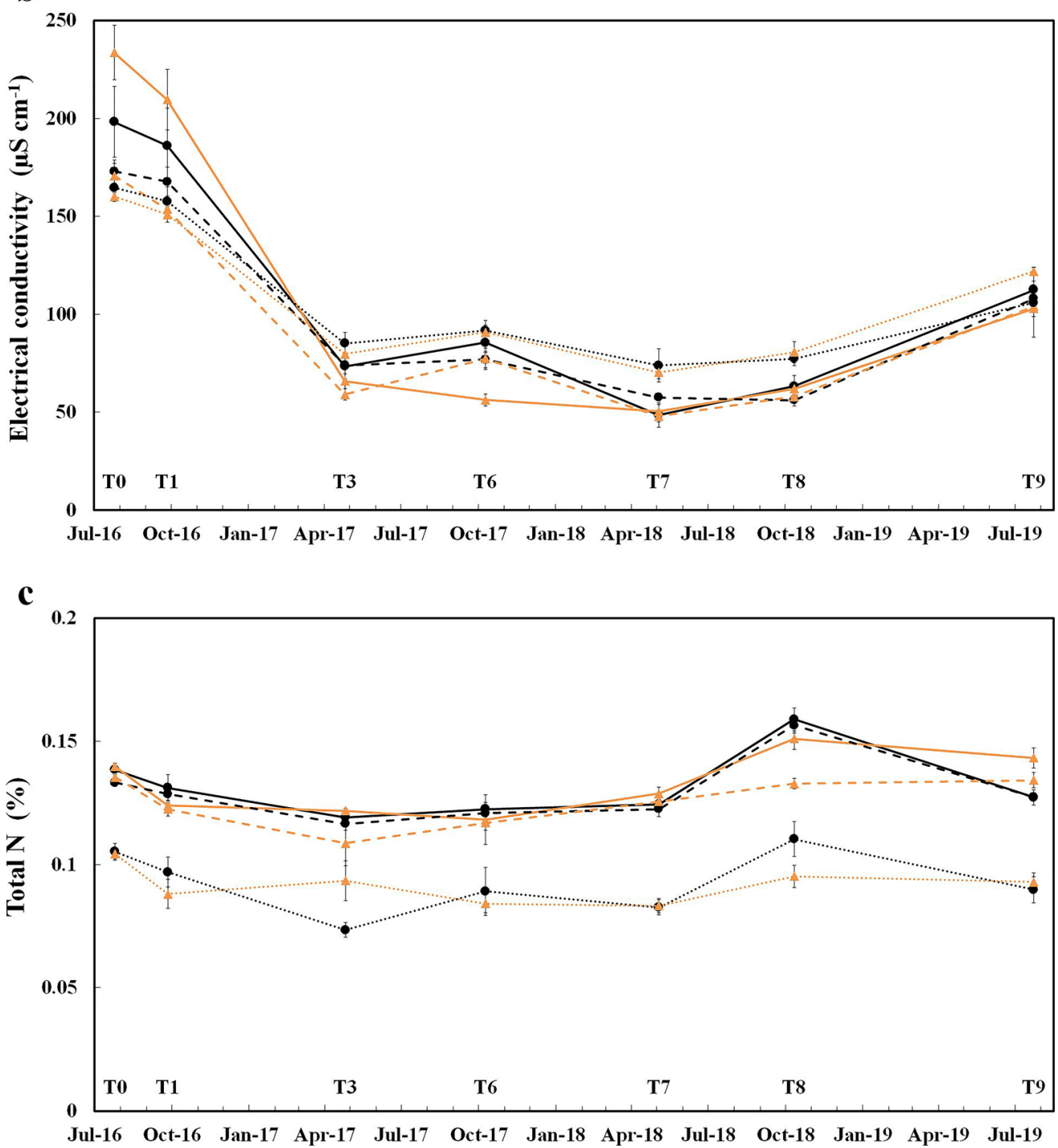


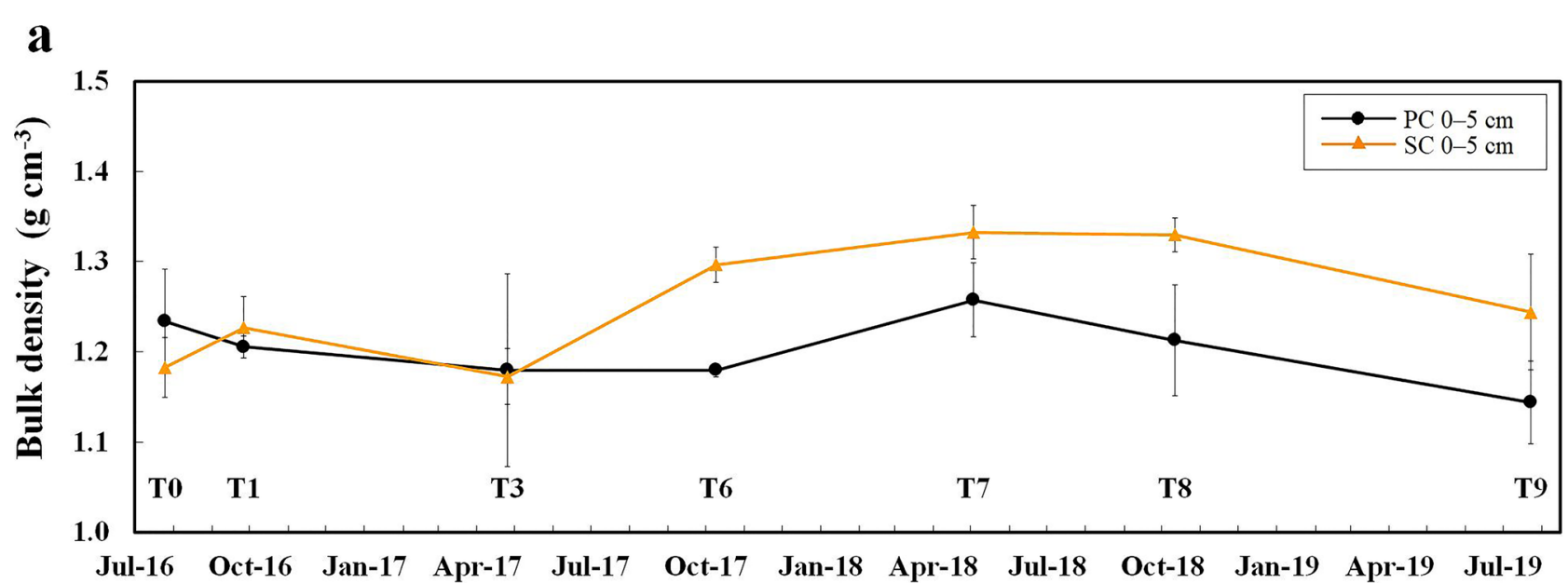

b

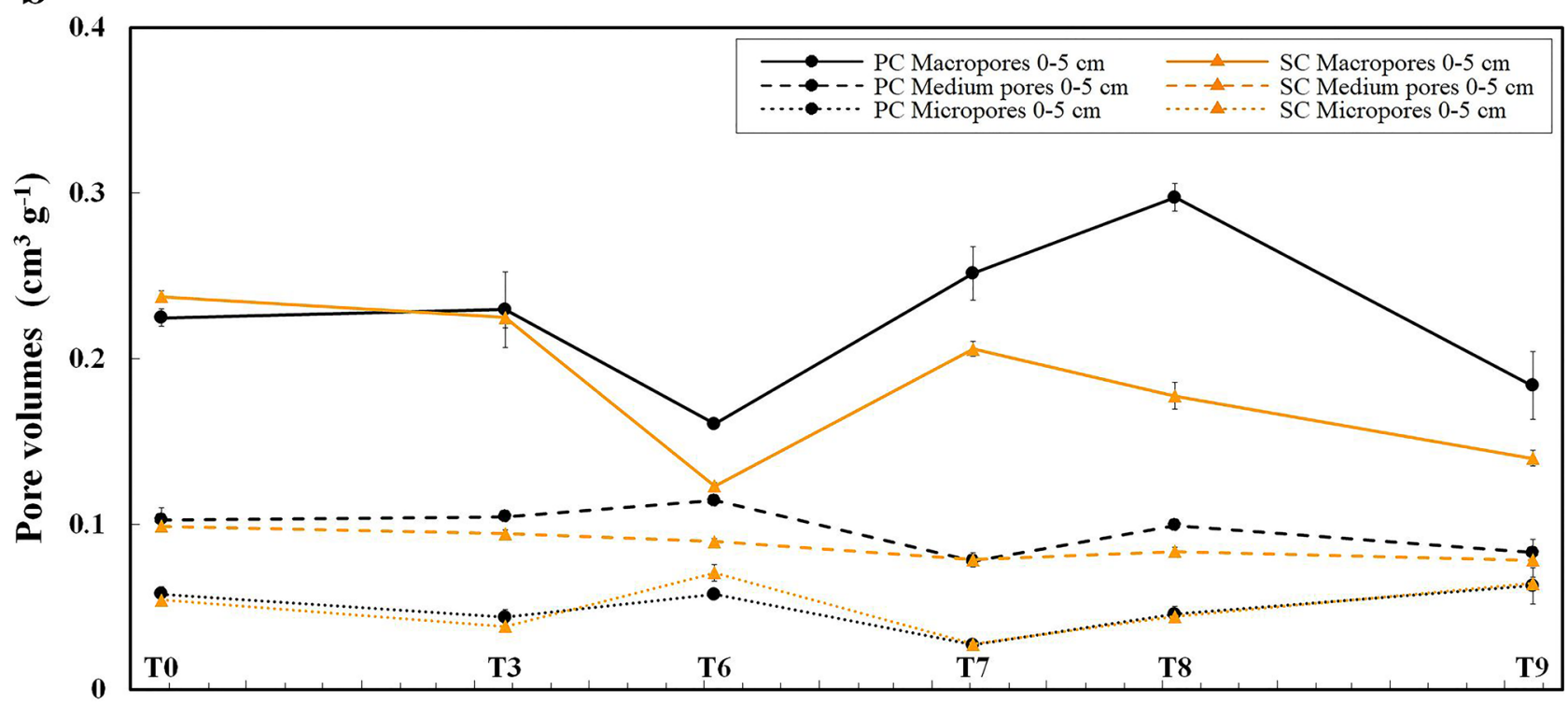

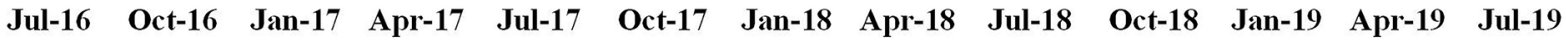

Fig. 3 Soil structural indicators. a Bulk density determined in the $0-5-\mathrm{cm}$ soil layer under plastic coverage (PC) and straw coverage (SC) at seven dates within the 3-year field experiment in strawberry cultivation (Fragaria $\times$ ananassa, 'Malwina'), respectively, shown as mean with standard error $(n=3)$. b Pore volumes of the macropore,

soil depth under SC, whereas under PC, the lowest and most delayed increase in soil moisture was observed at 5-cm soil depth.

\subsection{Physicochemical soil parameters}

The CEC (Table 1) was between 97 and $107 \mathrm{cmol} \mathrm{kg}^{-1}$ at $\mathrm{T} 0$ and increased in all soil layers under SC (7-18 cmol $\mathrm{kg}^{-1}$ ) and $\mathrm{PC}\left(6-12 \mathrm{cmol} \mathrm{kg}^{-1}\right)$ during the sampling period $(p<0.001)$.

The $\mathrm{pH}$, electrical conductivity, and total $\mathrm{N}$ (Fig. 2a-c) showed a similar pattern in their temporal fluctuations medium pore, and micropore domains (derived from quantitative pore size distributions) determined in the $0-5-\mathrm{cm}$ soil layer under plastic coverage (PC) and straw coverage (SC) at six dates within the 3-year field experiment in strawberry cultivation (Fragaria $\times$ ananassa, 'Malwina'), respectively, shown as mean with standard error $(n=3)$

during the sampling period. The $\mathrm{pH}$ was around 7.8 in all soil layer under both treatments at T0 and decreased to T7 by $\sim 1.3$ units $(p<0.001)$ and increased to T9 by $\sim 0.9$ units $(p<0.001)$. Similar to $\mathrm{pH}$, the electrical conductivity was between 160 and $234 \mu \mathrm{S} \mathrm{cm}^{-1}$ at T0 and strongly declined by $79-168 \mu \mathrm{S} \mathrm{cm}^{-1}$ in all soil layers to $\mathrm{T} 3$ $(p<0.001)$, remained between 50 and $90 \mu \mathrm{S} \mathrm{cm}^{-1}$ from $\mathrm{T} 3$ to $\mathrm{T} 8$, and increased again by $29-52 \mu \mathrm{S} \mathrm{cm}{ }^{-1}$ to $\mathrm{T} 9$ $(p<0.001)$. The total $\mathrm{N}$ was between 0.07 and $0.14 \%$ from T0 to T6 and showed a strong increase between T7 and T8 $(p<0.001)$ followed by a decrease to T9 $(p<0.001)$. This effect was stronger under PC $(\sim 0.03 \%)$ than under 
Fig. 4 Water-stable aggregate fractions of the 1-2-mm aggregate fraction determined in the $0-10-, 10-30-$, and 30-60-cm soil layers under plastic coverage (PC) and straw coverage (SC) at seven dates within the 3-year field experiment in strawberry cultivation (Fragaria $\times$ ananassa, 'Malwina'), respectively, shown as mean with standard error $(n=5)$

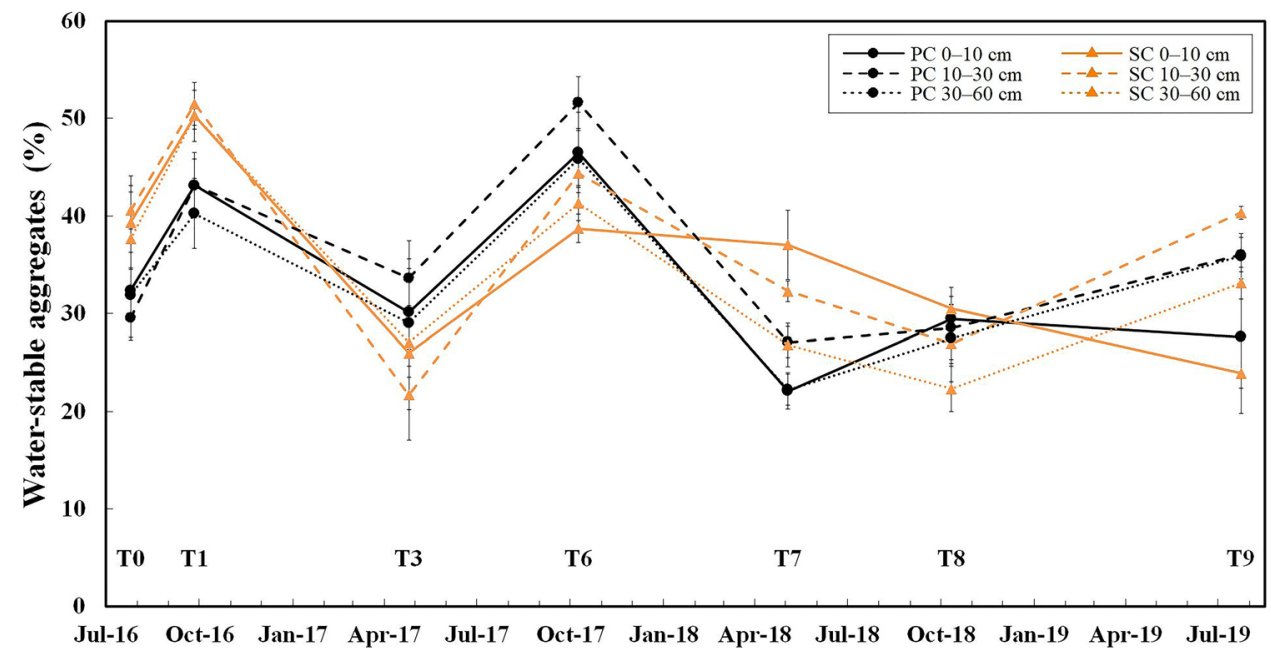

SC $(\sim 0.01 \%)$, such that total $\mathrm{N}$ was higher under $\mathrm{PC}$ at $\mathrm{T} 8$ $(10-30-\mathrm{cm}$ soil layer, $p<0.001)$ and lower at T9 $(0-10-$ $\mathrm{cm}$ soil layer, $p=0.015$ ) compared to SC. Mostly small differences and no clear trends were observed between treatments and soil layers for $\mathrm{pH}(<0.15$ units), electrical conductivity $\left(<15 \mu \mathrm{S} \mathrm{cm}^{-1}\right)$, and total $\mathrm{N}(<0.005 \%)$. Only total $\mathrm{N}$ in the $30-60-\mathrm{cm}$ soil layer of both treatments was on average $0.04 \%$ lower than in both upper layers $(p<0.001)$.

\subsection{Soil structural indicators}

The bulk density (Fig. 3a) was comparable in both treatments from T0 to T3 $\left(1.17-1.23 \mathrm{~g} \mathrm{~cm}^{-3}\right)$ but increased under $\mathrm{SC}$ to $1.33 \mathrm{~g} \mathrm{~cm}^{-3}$ at $\mathrm{T} 7(p=0.037)$ and was $0.08-0.12 \mathrm{~g} \mathrm{~cm}^{-3}$ higher under SC than under PC from T6 to T9 (T6, $p=0.016)$. The bulk density under PC did not change significantly during the experiment, but as a trend, a slight decrease was revealed from $\mathrm{T} 0\left(1.23 \mathrm{~g} \mathrm{~cm}^{-3}\right)$ to $\mathrm{T} 9$ $\left(1.14 \mathrm{~g} \mathrm{~cm}^{-3}\right)$.

Table 1 Cation-exchange capacity (CEC) determined in the 0-10-, 10-30-, and 30-60-cm soil layers under plastic coverage (PC) and straw coverage (SC) at the beginning (T0) and end (T9) of the 3-year field experiment in strawberry cultivation (Fragaria $\times$ ananassa, 'Malwina'), respectively, shown as mean with standard error $(n=5)$

\begin{tabular}{lrll}
\hline Sampling & Soil layer & PC & SC \\
& & CEC $\left(\mathrm{cmol} \mathrm{kg}^{-1}\right)$ & CEC $\left(\mathrm{cmol} \mathrm{kg}^{-1}\right)$ \\
\hline T0 (July 2016) & $0-10 \mathrm{~cm}$ & $106 \pm 2$ & $97 \pm 1$ \\
& $10-30 \mathrm{~cm}$ & $106 \pm 2$ & $102 \pm 3$ \\
& $30-60 \mathrm{~cm}$ & $107 \pm 2$ & $103 \pm 1$ \\
T9 (July 2019) & $0-10 \mathrm{~cm}$ & $114 \pm 5$ & $115 \pm 2$ \\
& $10-30 \mathrm{~cm}$ & $118 \pm 1$ & $112 \pm 1$ \\
& $30-60 \mathrm{~cm}$ & $113 \pm 4$ & $110 \pm 4$ \\
\hline
\end{tabular}

Treatment-related differences in the pore volumes (Fig. 3b, SI Fig. 5) in the 0-5-cm soil layer increased with increasing pore size and time from T0 to T8. Starting with comparable values at $\mathrm{T} 0$, the $\mathrm{PC}$ maintained a $0.04-0.12 \mathrm{~cm}^{3} \mathrm{~g}^{-1}$ larger macropore volume from $\mathrm{T} 6$ to T9 (T8, $p=0.001)$ and a $0.02-0.03 \mathrm{~cm}^{3} \mathrm{~g}^{-1}$ larger medium pore volume at $\mathrm{T} 6$ and $\mathrm{T} 8(\mathrm{~T} 8, p=0.038)$ compared to $\mathrm{SC}$, whereas the micropore volume remained unaffected. During the sampling period, the macropore volumes declined by 0.04 and $0.1 \mathrm{~cm}^{3} \mathrm{~g}^{-1}$ under PC and SC, respectively (SC, $p<0.001$ ), whereas the medium pore volumes decreased by $0.02 \mathrm{~cm}^{3} \mathrm{~g}^{-1}$ in both treatments $(p=0.011)$. The results of T6 were excluded from statistical analyses and should be carefully interpreted as three samples have to be discarded due to accidentally captured earthworms, which destroyed the samples during water saturation.

The weight percentage of the 1-2-mm aggregate fraction in soil (SI Fig. 6) showed no clear differences between treatments or soil layers but decreased from 47 to $58 \%$ at T0 to $22-32 \%$ at T7 $(p<0.001)$ and increased strongly to $71-80 \%$ at $\mathrm{T} 8(p<0.001)$. The water-stable aggregates (Fig. 4) showed large seasonal fluctuations (up to $30 \%$ ), which occurred simultaneously but with different extents in all soil layers of both treatments from T0 to T7. A seasonal pattern was observed (exception T8) with a low water-stable aggregate fraction in spring (22-32\%), an intermediate water-stable aggregate fraction in summer (28-41\%), and a high water-stable aggregate fraction in autumn (39-52\%). The effects of treatment and soil layers were mostly $<10 \%$ and hardly interpretable because of the large standard errors. However, as a trend, the water-stable aggregate fractions under PC were larger at $\mathrm{T} 3$ and $\mathrm{T} 6$ and smaller at $\mathrm{T} 1$ and $\mathrm{T} 7$ compared to SC. The largest water-stable aggregate fractions were (mostly) found in the $10-30-\mathrm{cm}$ soil layer of both treatments. The 


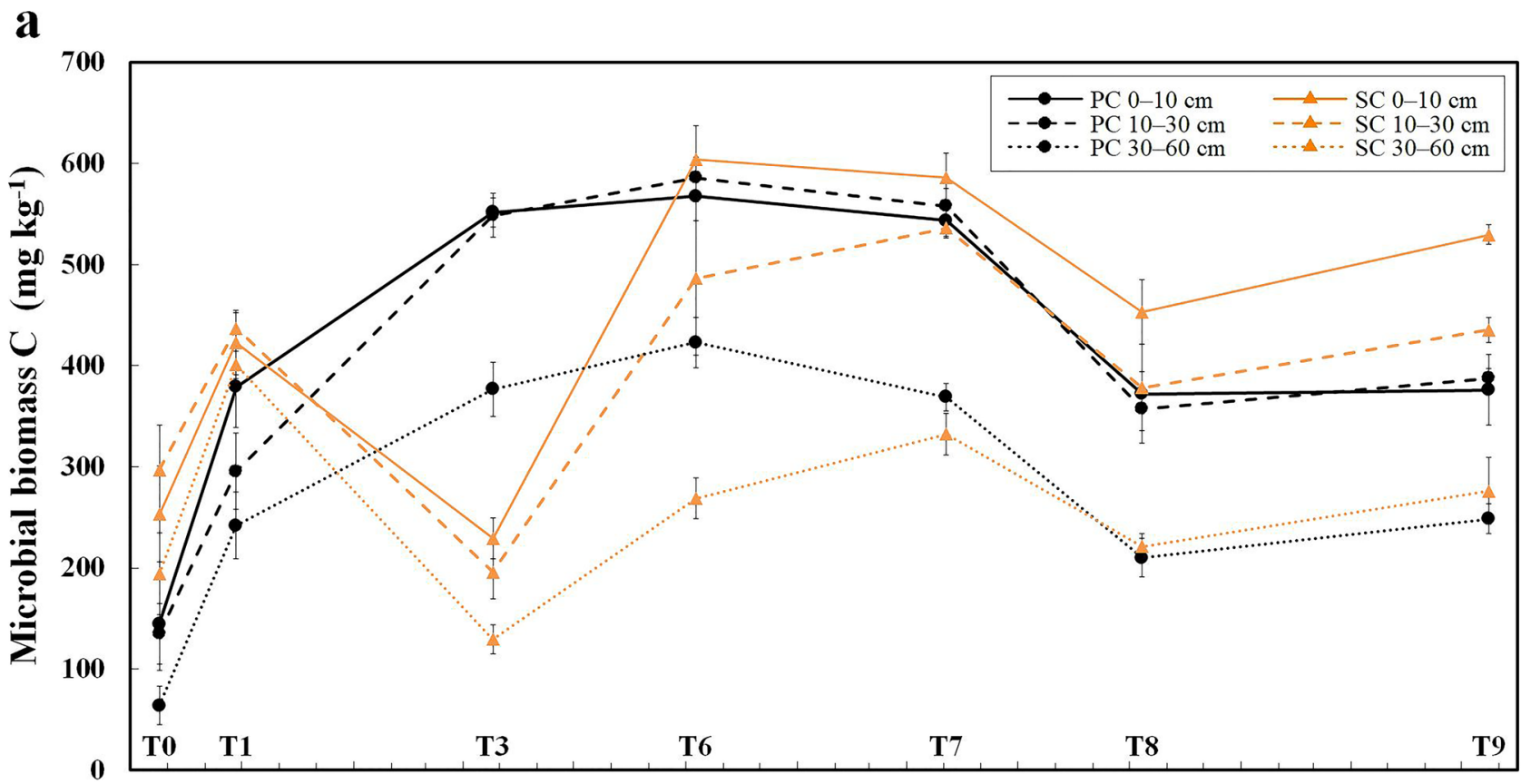

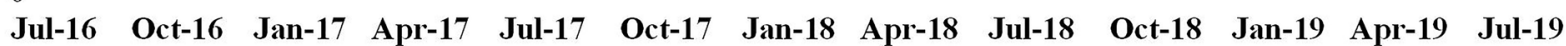

b

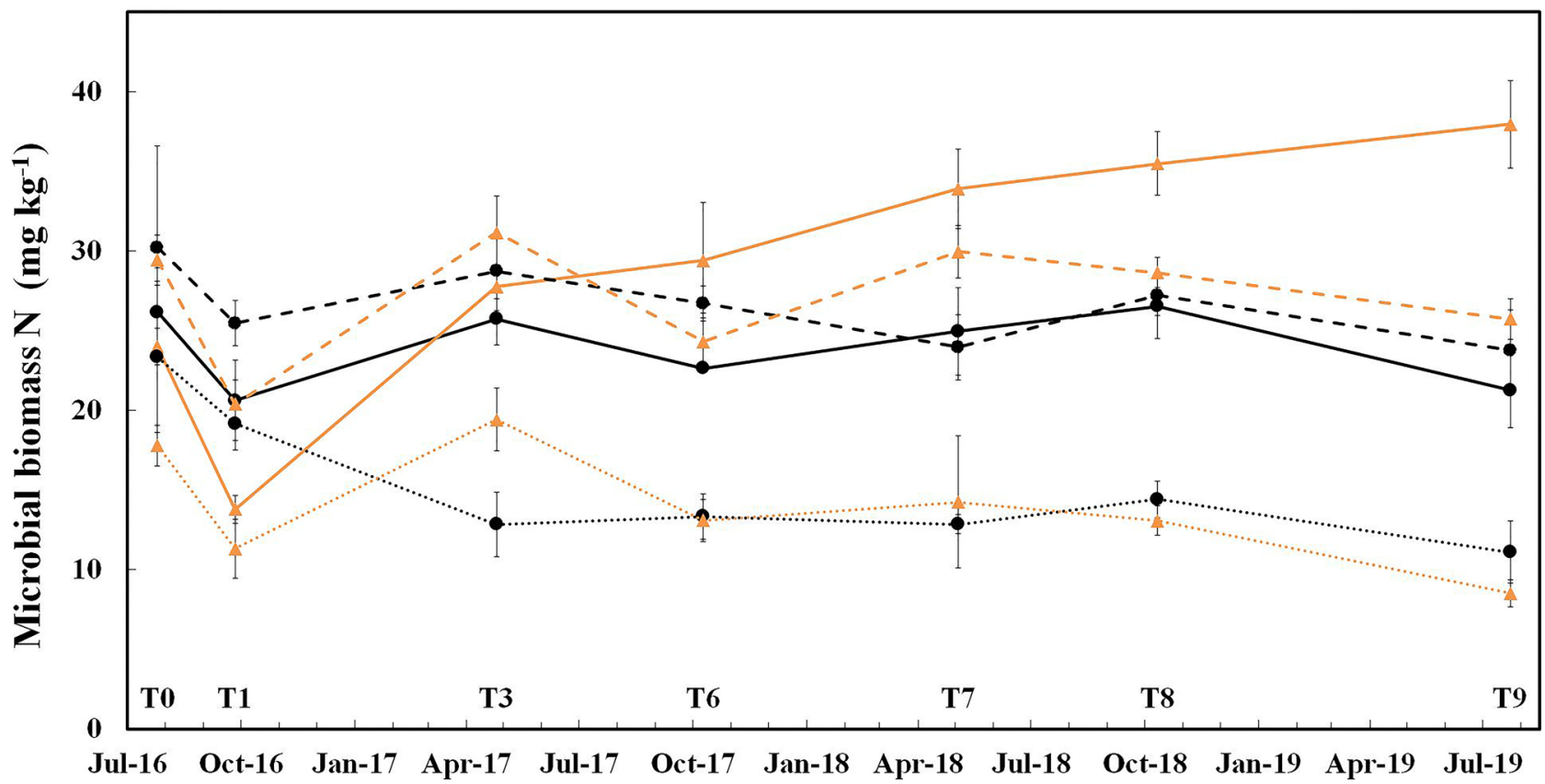

Fig. 5 Soil microbial biomass. a Soil microbial biomass carbon determined in the 0-10-, 10-30-, and 30-60-cm soil layers under plastic coverage (PC) and straw coverage (SC) at seven dates within the 3-year

water-stable aggregates correlated positively with CEC $\left(r_{S}=0.264, p=0.041, n=60\right), \mathrm{pH}\left(r_{S}=0.188, p=0.006\right.$, $n=210)$, electrical conductivity $(r=0.341, p<0.001$, $n=210)$, MBC $(r=0.231, p=0.001, n=210)$, and DOC $(r=0.335, p<0.001, n=180)$. field experiment in strawberry cultivation (Fragaria $\times$ ananassa, 'Malwina'), respectively, shown as mean with standard error $(n=5)$. b Soil microbial biomass nitrogen

\subsection{Soil organic matter}

Generally, MBC (Fig. 5a) increased by $2-7$ times to $269-604 \mathrm{mg} \mathrm{kg}^{-1}$ in all soil layers of both treatments from T0 to T6/7 $(p<0.006)$, whereas the MBC at T8 and T9 


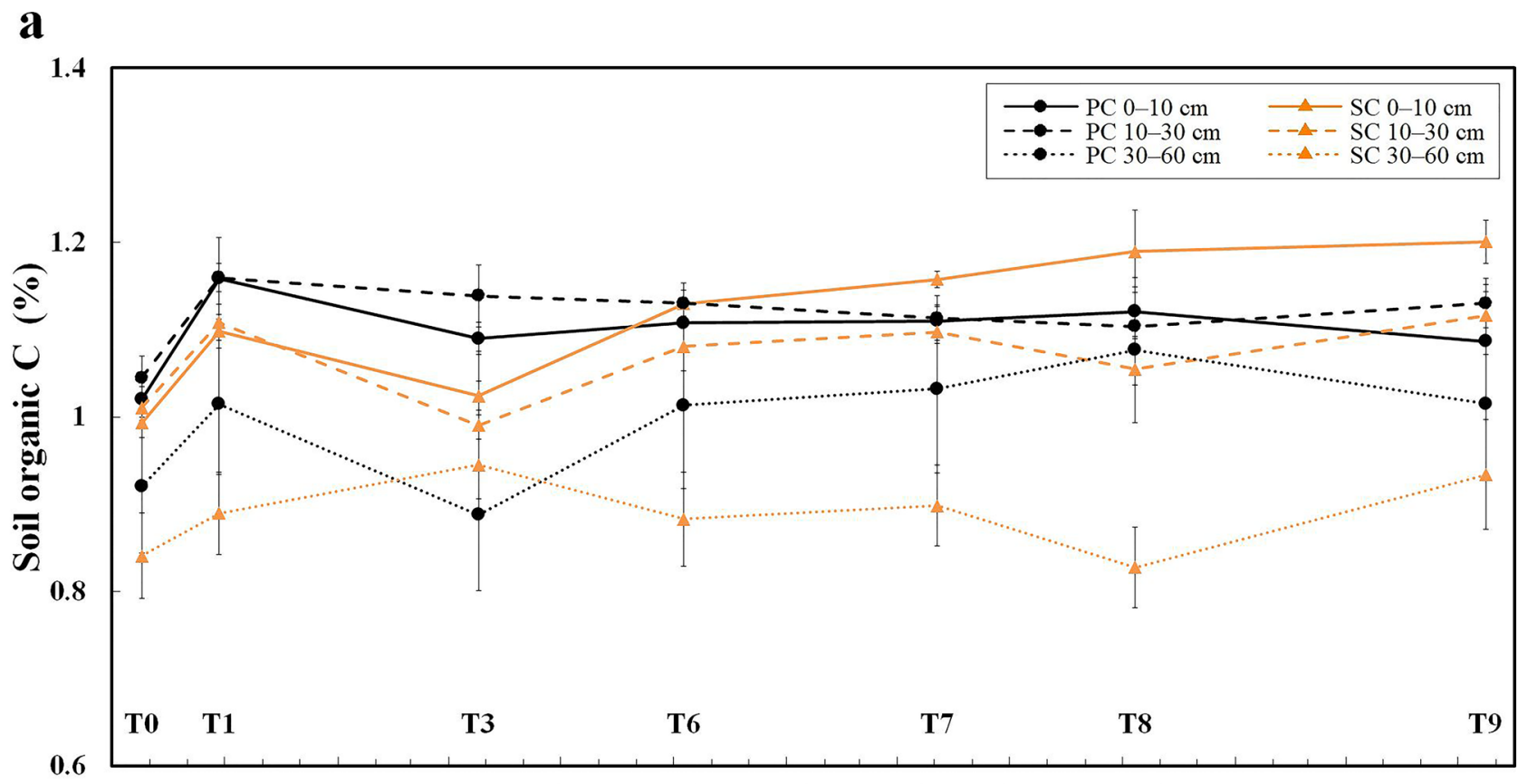

$\begin{array}{lllllllllllll}\text { Jul-16 } & \text { Oct-16 } & \text { Jan-17 } & \text { Apr-17 } & \text { Jul-17 } & \text { Oct-17 } & \text { Jan-18 } & \text { Apr-18 } & \text { Jul-18 } & \text { Oct-18 } & \text { Jan-19 } & \text { Apr-19 } & \text { Jul-19 }\end{array}$

b

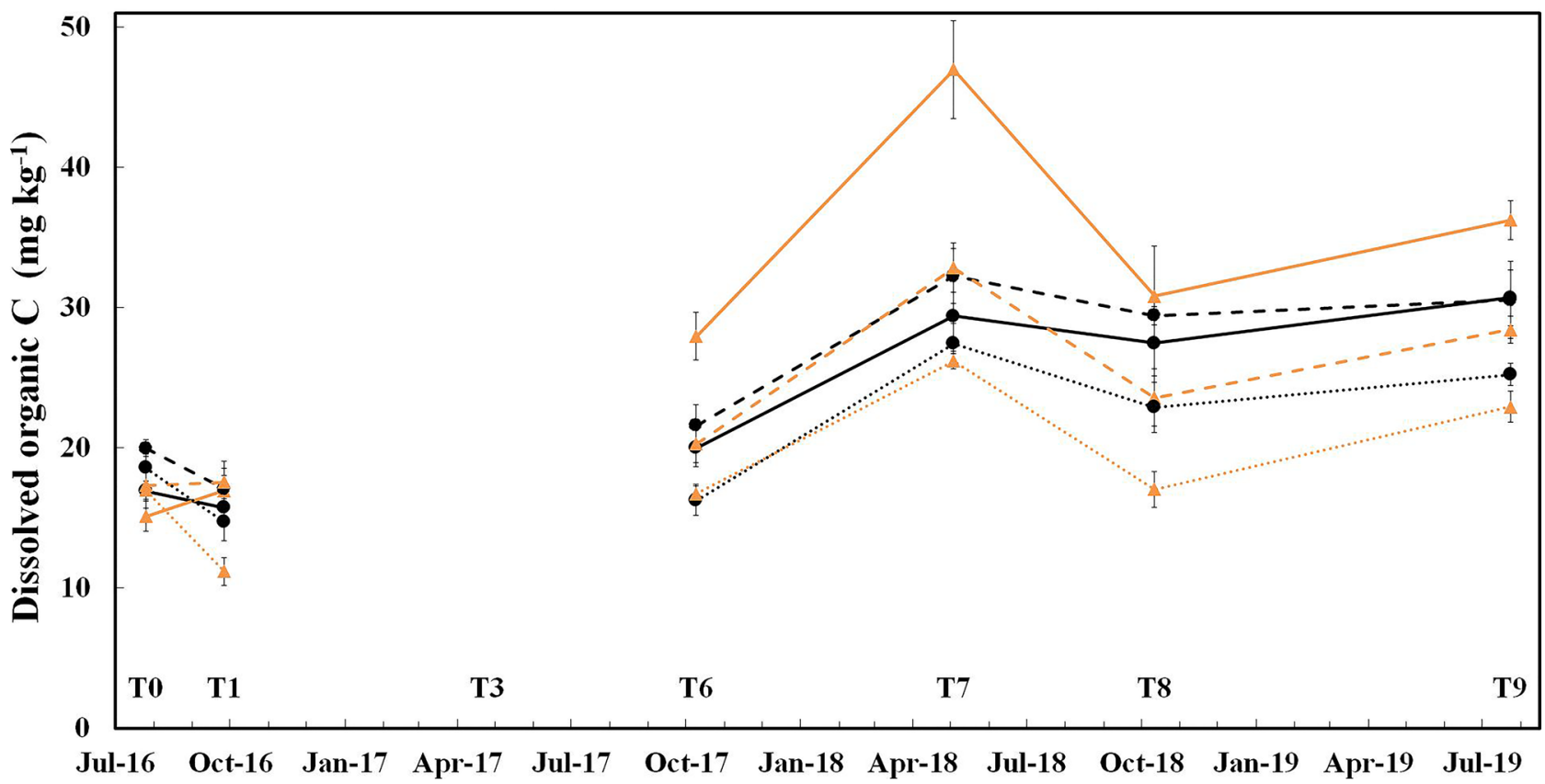

Fig. 6 Soil organic matter. a Soil organic carbon determined in the 0-10-, 10-30-, and 30-60-cm soil layers under plastic coverage (PC) and straw coverage (SC) at seven dates within the 3-year field experi-

was $210-530 \mathrm{mg} \mathrm{kg}^{-1}$ lower than at $\mathrm{T} 6 / 7$, but still $1.5-4$ times higher than at T0 $(p<0.024)$. At T3, the MBC under SC strongly decreased in all soil layers, leading to a 247-352 $\mathrm{mg} \mathrm{kg}^{-1}$ lower MBC under SC compared to PC $(p<0.001)$, but MBC fully recovered to T6. In the $0-10-\mathrm{cm}$ ment in strawberry cultivation (Fragaria $\times$ ananassa, 'Malwina'), respectively, shown as mean with standard error $(n=5)$. b Dissolved organic carbon

soil layer, the $\mathrm{MBC}$ under $\mathrm{SC}$ was higher than under $\mathrm{PC}$ from T6 to T9 (T9, $p=0.010$ ) and showed gradually increasing differences between treatments $\left(36-154 \mathrm{mg} \mathrm{kg}^{-1}\right)$.

The MBN (Fig. 5b) was $18-30 \mathrm{mg} \mathrm{kg}^{-1}$ at T0 and decreased during the sampling period by $3.7-12.2 \mathrm{mg} \mathrm{kg}^{-1}$ 
in all soil layers of both treatments $(p<0.001$, with a stronger effect under PC and with increasing soil depth), with exception of the $0-10-\mathrm{cm}$ soil layer under SC, where MBN increased by $14 \mathrm{mg} \mathrm{kg}^{-1}(p<0.001)$. Similar to MBC, the increase in $\mathrm{MBN}$ in the $0-10-\mathrm{cm}$ soil layer led to a higher
MBN under SC compared to PC (T7, T8, and T9, $p<0.043$ ) with gradually increasing differences between the treatments $\left(2.0-16.7 \mathrm{mg} \mathrm{kg}^{-1}\right)$.

The SOC (Fig. 6a) ranged from 0.83 to $1.20 \%$ and was higher under PC compared to SC in all soil layers during

$\mathbf{a}$

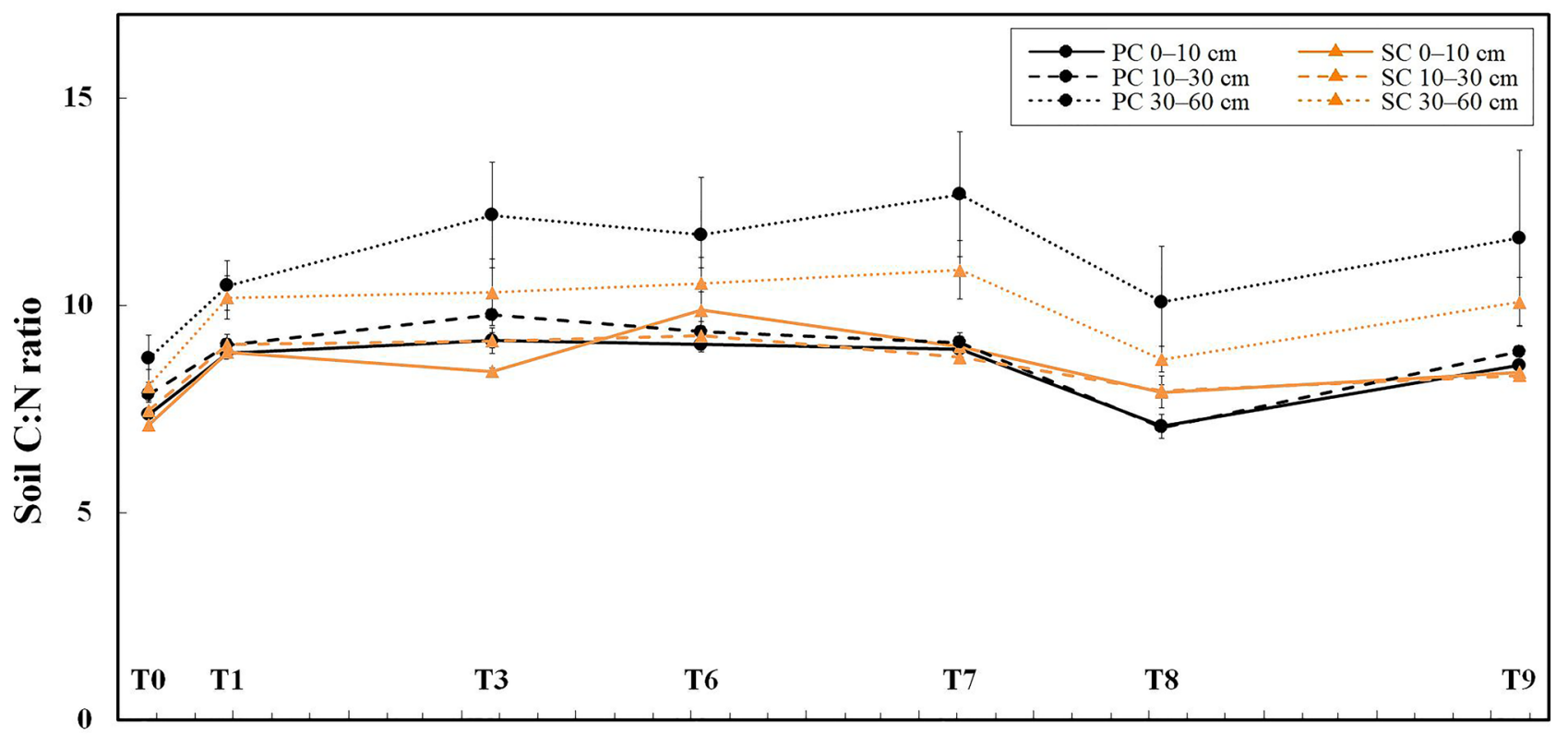

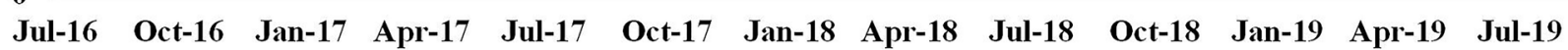

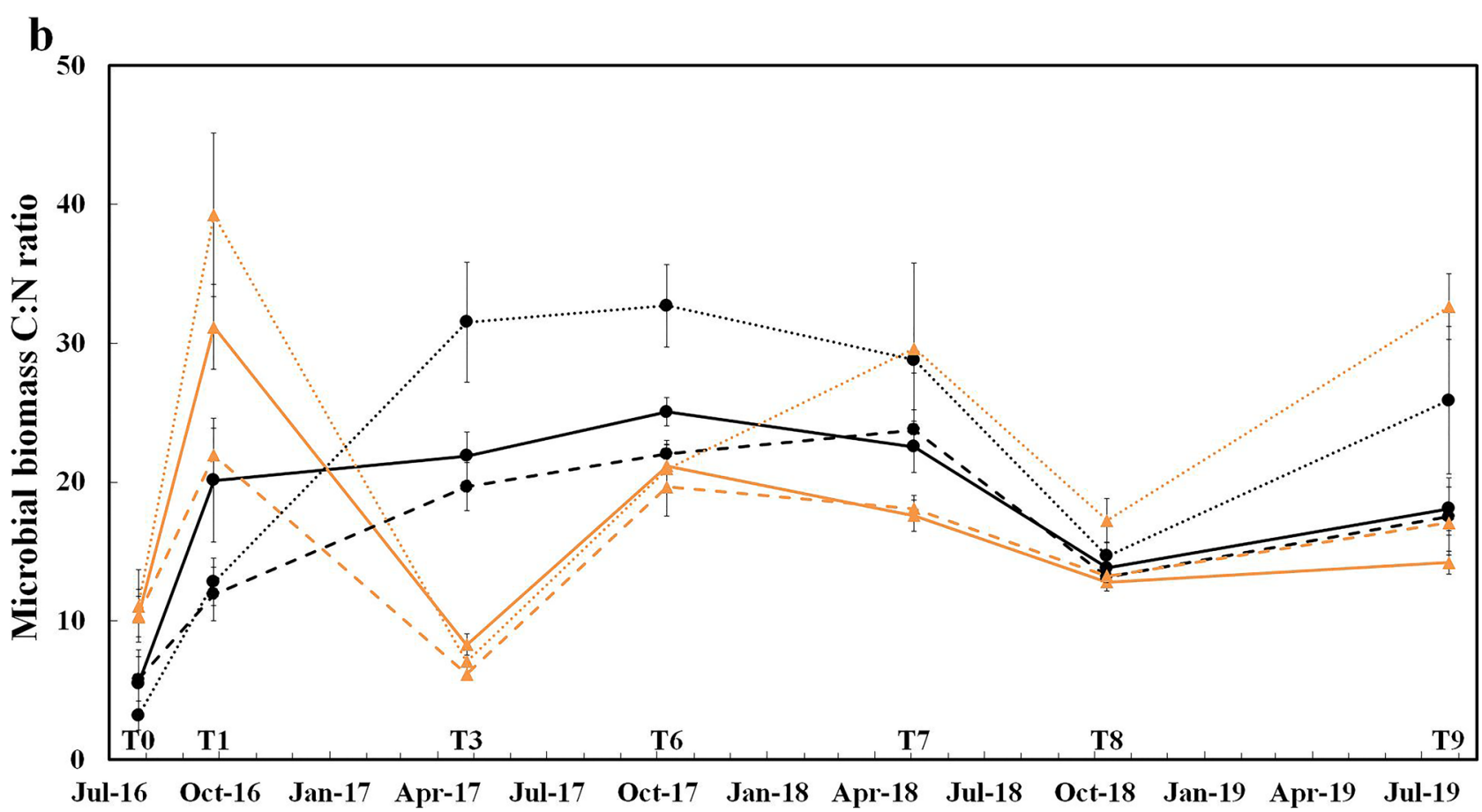

Fig. 7 Soil organic matter ratios. a C:N ratio determined in the $0-10-$, 10-30-, and 30-60-cm soil layers under plastic coverage (PC) and straw coverage (SC) at seven dates within the 3-year field experiment in strawberry cultivation (Fragaria $\times$ ananassa, 'Malwina'), respectively, shown as mean with standard error $(n=5)$. b MBC:MBN ratio 
the sampling period with largest differences between treatments in the 30-60-cm soil layer (up to $0.25 \%$ ). However, this trend changed in the $0-10-\mathrm{cm}$ soil layer during the sampling period, and from $\mathrm{T} 6$ to $\mathrm{T} 9$, higher SOC values were observed under SC $(0.02-0.11 \%)$, with gradually increasing differences between treatments (T3, T7, and T9, $p<0.045$ ). The SOC showed a strong increase $(0.05-0.14 \%)$ in all soil layers of both treatments from T0 to T1 $(p<0.001)$. From $\mathrm{T} 1$ until $\mathrm{T} 9$, the SOC revealed a trend to increase under $\mathrm{SC}$ and to decrease under PC in all soil layers (exception, 30-60-cm soil layer under PC). These effects decrease with increasing soil depth. The SOC correlated positively with $\mathrm{CEC}\left(r_{S}=0.283, p=0.028, n=60\right)$.

Because the DOC at T3 (SI Fig. 7) was unrealistically high with values of 494-1024 mg kg-1 (> $2000 \mathrm{mg} \mathrm{kg}^{-1}$ in some replicates) and we did not find a valid explanation for the high values nor can exclude a mistake during the determination process (no filtration maybe), the DOC at T3 was excluded from interpretation and statistical analyses. The DOC (Fig. 6b) ranged from 7 to $47 \mathrm{mg} \mathrm{kg}^{-1}$ and was $1-18 \mathrm{mg} \mathrm{kg}^{-1}$ higher under SC than under PC in the 0-10$\mathrm{cm}$ soil layer from T1 to T9 (T6 and T7, $p<0.007$ ), whereas in both soil layers below the topsoil, a tendency to the opposite was observed. During the sampling period, the DOC increased by $6-21 \mathrm{mg} \mathrm{kg}^{-1}$ in all soil layers (effect decrease with increasing soil depth) of both treatments $(p<0.001)$. The DOC showed a tendency to have a seasonal pattern with a high DOC in April, an intermediate DOC in July, and a low DOC in October, which is the opposite of what was observed with water-stable aggregates.

Generally, the C:N ratios (Fig. 7a) were between 7.1 and 16.1 during the sampling period. After an initial increase from T0 to T1 in all soil layers of both treatments, the C:N ratios in the 30-60-cm soil layer were by $1.2-1.9$ units higher under $\mathrm{PC}$ than under $\mathrm{SC}$ from $\mathrm{T} 3$ to $\mathrm{T} 9$. In this period, the C:N ratios were by $0.9-2.9$ units higher than at T0 (except at T8) in all soil layers of both treatments $(p<0.002)$. In both treatments, the largest $\mathrm{C}: \mathrm{N}$ ratios were found in the 30-60-cm soil layer $(p<0.005)$.

The MBC:MBN ratios (Fig. 7b) were between 3 and 39 and were by $10-26$ units lower in all soil layers under PC than under SC at T1 $(p<0.021)$. However, the MBC:MBN ratios were 14-28 units wider in all soil layers under $\mathrm{PC}$ from $\mathrm{T} 0$ to $\mathrm{T} 3$, which led to mostly wider MBC:MBN ratios under PC from $\mathrm{T} 3$ to $\mathrm{T} 9$, with differences between treatments of up to 25 units (T3, $p<0.004 ; 30-60$-cm soil layer at T6, $p=0.013 ; 10-30$-cm soil layer at T7, $p=0.014)$. Generally, the MBC:MBN ratios became wider during the sampling period $(p<0.001)$; however, this effect was stronger in all soil layers under PC $(13,12$, and 23$)$ than under SC $(4,7$, and 22).

All three SOM fractions (Fig. 8a-c) revealed temporal fluctuations in all soil layers of both treatments and partly large data scattering, which makes it difficult to identify any treatment- or depth-specific differences. However, as a trend, the free SOM in the $0-10-\mathrm{cm}$ soil layer increased by $0.9 \mathrm{~g} \mathrm{~kg}^{-1}$ under $\mathrm{SC}$ and decreased by $1.8 \mathrm{~g} \mathrm{~kg}^{-1}$ under PC during the sampling period, which resulted in a higher free SOM under SC compared to PC from T6 to T9 $\left(0.4-1.3 \mathrm{~g} \mathrm{~kg}^{-1}\right)$. The mineral-associated SOM showed a tendency to higher values under PC than under SC in all soil layers (exception, $0-10$-cm soil layer from $\mathrm{T} 7$ to $\mathrm{T} 9$ ).

\section{Discussion}

\subsection{Influence of soil coverage on rainfall infiltration and leaching}

The delayed and smaller increases in soil moisture after rainfalls and the considerably lower soil moisture at 5-cm soil depth under PC compared to SC indicated that PC strongly reduces rainfall infiltration and excess water at the soil surface and thus seepage water flows, which was expected to reduce leaching under PC (Lal 2006). In contrast to the downward-directed seepage water flows, hints were observed to lateral and ascending water flows after rainfalls under PC, presumably induced by lateral pressure heads between ridges and furrows (Ruidisch et al. 2013). This points to an upward and laterally directed particle and substance relocation, which can counteract leaching. However, clear indications for the hypothesized reduced leaching under PC were observed neither in total $\mathrm{N}$ nor in electrical conductivity during the sampling period. However, Meyer et al. (2020) described reduced leaching under PC compared to bare soil in the establishment period of strawberries (the first 4 months of the experiment). Thus, we conclude that leaching might also been mitigated under SC due to a decelerated rainwater infiltration by the straw mulch (applied in April 2017) and rainfall interception by the densely grown plant canopy (Gan et al. 2013). Additionally, a stronger nitrogen (nutrient) uptake under PC (Subrahmaniyan et al. 2006; Kumar and Dey 2011), because of stronger plant growth (Kumar and Dey 2011; Gan et al. 2013; Zhang et al. 2017), could have compensated the nitrogen (nutrient) gains due to omitted leaching losses. The yearly fertilization from March until May seem to have no influence on $\mathrm{pH}$, electrical conductivity, and total $\mathrm{N}$, which might indicate a good fertilizer use efficiency.

\subsection{Influence of soil coverage on pore volumes and soil structure}

Under PC, a lower bulk density and a higher macropore volume became observable in the surface soil $(0-5 \mathrm{~cm})$ after 1 year, which was presumably governed by two processes: 


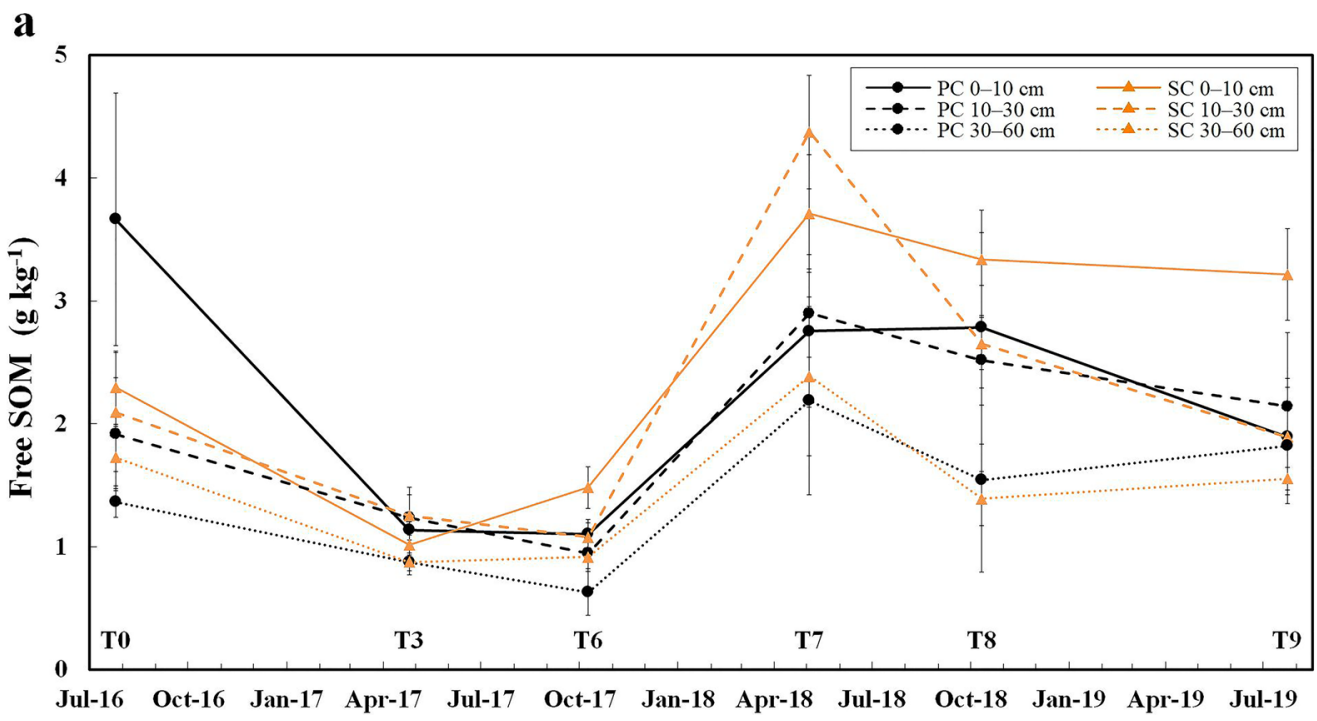

b

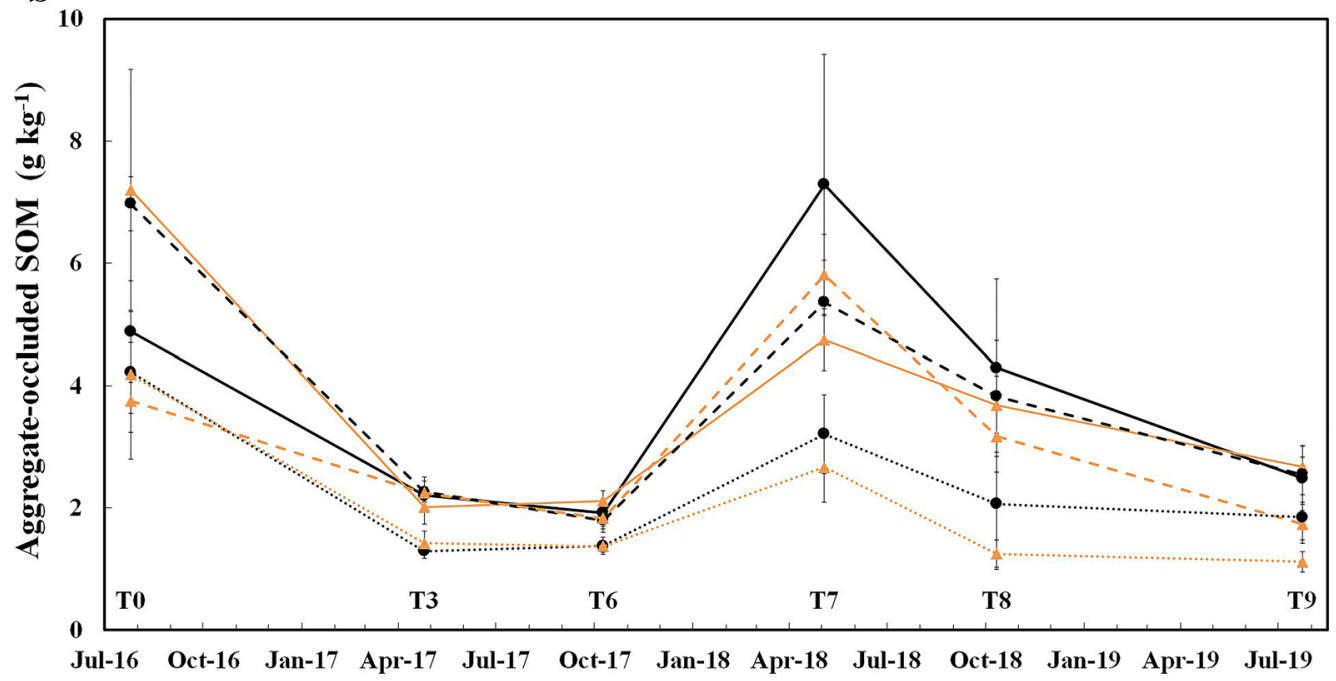

c

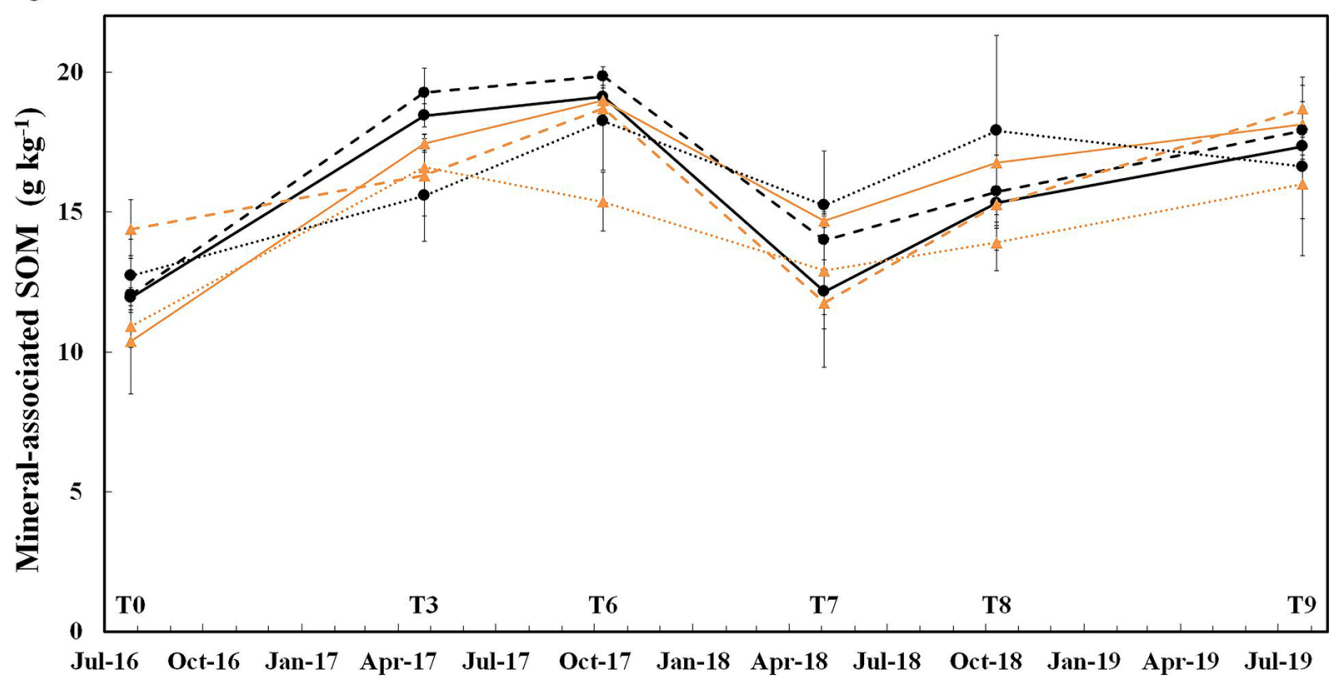


4Fig. 8 Soil organic matter composition. a Free soil organic matter (SOM) determined in the 0-10-, 10-30-, and 30-60-cm soil layers under plastic coverage (PC) and straw coverage (SC) at seven dates within the 3-year field experiment in strawberry cultivation (Fragaria $\times$ ananassa, 'Malwina'), respectively, shown as mean with standard error $(n=5)$. b Aggregate-occluded SOM. c Mineralassociated SOM

In contrast to $\mathrm{SC}$, the water-impermeable $\mathrm{PC}$ avoids rapid soil wetting after rainfalls, which prevents aggregate slaking, physicochemical dispersion, and particle relocation and thus soil crusting and compaction (Bing So 2006; Le Bissonnais 2006). Soil crusting and compaction reduce water infiltration, increase runoff, and consequently make soils more prone to erosion (Le Bissonnais 2006). Secondly, the bulk density slightly decreased under PC during the sampling period, which was not reflected in increasing macropore volumes and thus might be caused by larger root growth under PC (Fernandez et al. 2001; Kumar and Dey 2011). Thus, PC maintained a more loose and friable soil structure in the surface soil compared to SC, which made soil less prone to erosion and promotes good aeration, soil warming, rooting, and water retention and, thus, soil quality and agronomic productivity (Bronick and Lal 2005; Le Bissonnais 2006). However, no increase in the (water-)stability of macroaggregates was observed in the topsoil under PC compared to $\mathrm{SC}$, despite the impeded (disruptive) raindrop impact on aggregates at the soil surface and the lower soil moisture under PC (Bing So 2006; Blanco-Canqui and Lal 2006). Presumably, the straw mulch and the dense plant canopy reduced raindrop impact on aggregate stability also under $\mathrm{SC}$; therefore, the physical impact of raindrops on surface soil seems to have only a minor role for the aggregate stability in both treatments. As Sintim et al. (2021) found a higher aggregate stability in the topsoil after 4 years of continuous plastic mulching, we cannot exclude that effects on aggregate stability would not appear during an extended experiment period.

\subsection{Influence of soil coverage on soil microbial biomass and aggregate formation and stability}

As described in numerous studies, PC increased soil temperature (reviewed in Gan et al. 2013; Steinmetz et al. 2016), which is generally attributed to the optical properties of the mulch and its impact on the heat transfer between soil surface and surroundings (Tarara 2000). In contrast to the higher soil moisture under plastic mulching, attributed to a reduced evaporation in semiarid and arid regions (e.g., Gan et al. 2013; Wang et al. 2015), our results showed a predominantly lower soil moisture under PC compared to $\mathrm{SC}$, especially in the topsoil. This suggests that under humid climate, impeded rainfall infiltration strongly outweighs the effect of reduced evaporation (Meyer et al. 2020). Similarly, a lower soil moisture under PC was also found in a study conducted by Schirmel et al. (2018) under humid conditions in Southwestern Germany. The seasonal effects on soil temperature presumably depend on seasonal changes in solar radiation but additionally also on wind, cloudiness, and density of plant canopy. In winter, the missing irrigation combined with impeded rainfall infiltration under PC might have led to the increasing soil moisture differences between PC and SC in the topsoil $(0-10 \mathrm{~cm})$. Although the subsoil under $\mathrm{PC}$ received more water after rainfalls compared to $\mathrm{SC}$, the soil moisture decreased more strongly afterwards and led especially in summer and autumn to a clearly lower soil moisture under PC. This might be explained by a higher water uptake of the plants and ascending water flows to the drier upper soil layers (Tarara 2000; Wang et al. 2014).

Several studies found a higher MBC under PC, which was mainly attributed to the elevated soil temperature and moisture under PC (e.g., Gan et al. 2013; Luo et al. 2015; Yang et al. 2018). In spite of partly up to $6.5^{\circ} \mathrm{C}$ higher soil temperatures under PC, a clearly larger MBC under PC was only found at T3 (April 2017) and partly at T6 (October 2017 ) in the 3-year study. Maybe the partly lower soil moisture under PC compensated for the expected positive effect of soil temperature on MBC. However, as differences in soil temperature and moisture between coverage types were soiland depth-specific but were not reflected in $\mathrm{MBC}$, it can be concluded that these differences were not large enough to shape different MBC under the investigated coverage types. The higher MBC and MBN in the topsoil under SC compared to PC from T6 to T9 were presumably caused by the incorporation of straw and aboveground biomass into soil (Bünemann et al. 2006; Huo et al. 2017). This implies, in contrast to the differences in soil temperature and moisture, a strong and gradually increasing treatment effect on microbial biomass.

Wang et al. (2017) described a 16-28\% increase in the water-stable macroaggregate fraction under $\mathrm{PC}$, which they attributed to an increased root growth and microbial activity under PC. In contrast to Wang et al. (2017), no clear positive effects of PC on aggregation and aggregate stability was found in this study. This is in accordance with the results of microbial biomass, which was hypothesized as main driver for an increased aggregate formation and stability under PC. However, a strong influence of microorganisms on aggregate stability was confirmed by the highly significant positive correlation between MBC and water-stable aggregates. Generally, aggregation and aggregate stability are influenced by a multitude of factors such as soil moisture, SOM, root growth, fungal hyphae, exudation of roots and microbes, and wetting-drying cycles (Bronick and Lal 2005). This is reflected in the observed positive correlation between waterstable aggregates and $\mathrm{pH}$, electrical conductivity, $\mathrm{MBC}$, and DOC. Thus, the increasing aggregate stabilities from spring 
to autumn and their strong variations between sampling time points and treatments are likely the result of several processes (co-)occurring during the sampling period. The largest water-stable aggregate fraction found in the root layer $(10-30 \mathrm{~cm})$ and increasing aggregate stabilities from spring to autumn point to a large influence of root growth and exudation (Tisdall and Oades 1982; Bronick and Lal 2005). However, more detailed studies are necessary to break down the individual processes that govern aggregate stability and elucidate how they are influenced by soil coverage and how much they contribute to the observed variations.

\subsection{Influence of soil coverage on entry and decomposition of soil organic matter}

The general increase in SOC under both treatments after strawberry establishment was attributed to the strong root growth of the plants (Meyer et al. 2020). This increase in SOC was stronger under PC, presumably because of a larger root growth and exudation under PC due to the higher soil temperature (Fernandez et al. 2001; Kumar and Dey 2011; Yin et al. 2013). This results in a larger SOC under PC than under SC (especially in the 30-60-cm soil layer), even though the aboveground biomass entry under PC was impeded by the impermeable plastic mulch. Similarly, Luo et al. (2015) described higher SOC stocks in the 20-40-cm soil layer under plastic mulching, which they attributed to improved rooting systems and increased root biomass. However, this effect was compensated for in the topsoil $(0-10 \mathrm{~cm})$ after 1 year (T6), and from T6 to T9, the SOC was higher under SC compared to PC, which resulted most likely from the SOM entry under SC due to decaying straw mulch and plant residues. The higher DOC in the topsoil under SC supports this assumption as DOC mainly derives from fresh plant residues or decomposition by-products (Bolan et al. 2011). In contrast, the partially higher DOC in the 10-30and 30-60-cm soil layers under PC might originate from higher root exudation or small organic molecules transported from straw-covered furrows to ridges by lateral water flows under PC (Bolan et al. 2011; Ruidisch et al. 2013). Former studies found reduced SOM under PC, which was attributed to an accelerated SOM decomposition due to changes in microclimate and microorganisms (e.g., Li et al. 2004, 2007; Zhang et al. 2015). However, despite higher soil temperatures, increasing $\mathrm{MBC}$, and an impeded aboveground biomass entry under PC, no increased SOM losses were found in this 3-year study under temperate, humid climate conditions. This suggests that an accelerated SOM decomposition under PC, which would result in reduced SOM stocks, can either be excluded or be compensated for by other processes like, e.g., biomass entry due to root growth and exudation under the present conditions (Fernandez et al. 2001; Kumar and Dey 2011; Yin et al. 2013). Reduced SOM stocks could be critical for soil quality and productivity and would question the sustainability of the management practice (Haynes 2005; Steinmetz et al. 2016). It can be speculated that in arid and semiarid regions, where microbial activity and thus SOM decomposition are usually strongly restricted by the low soil moisture (Coûteaux et al. 1995; Butenschoen et al. 2011), elevated soil moisture under plastic mulching (Gan et al. 2013) might strongly trigger SOM decomposition. In contrast to that, soil moisture under humid conditions is not elevated by plastic mulching and generally high enough to enable decomposition.

\subsection{Influence of soil coverage on quality and composition of soil organic matter}

The still rarely investigated influence of soil coverage on SOM composition and hence SOM quality (Steinmetz et al. 2016) as estimated by density fractionation revealed a positive effect of SC on free SOM (topsoil) and of PC on mineral-associated SOM. The free SOM fraction refers to the active SOM pool (turnover time of 1-2 years) and represents (often combined with aggregate-occluded SOM) the light SOM fraction (von Lützow et al. 2006, 2007). The light SOM fraction consists mainly of a fresh and fast-mineralizable SOM (e.g., plant residues, microbial biomass), which is important for the nutrient supply in soil (Wander 2004; von Lützow et al. 2006). Thus, the lower free SOM in the topsoil under PC from T6 to T9 corroborated our assumption of an impeded aboveground SOM entry into soil compared to SC and point to a lower short-term nutrient supply under PC (Wander 2004). Similarly, Wang et al. (2016) found decreased light SOC fraction under multiannual PC use compared to nonmulched plots and an increased light SOC fraction after straw incorporation. The mineral-associated SOM fraction refers to the passive SOM pool (turnover time of 100 to $<1000$ years), which consists of older, more degraded, recalcitrant SOM, often bound in organo-mineral complexes (von Lützow et al. 2006, 2007). The passive SOM pool is of great relevance for long-term SOM stabilization, soil structure, nutrient sorption, and water-holding capacity (Wander 2004; Grego and Lagomarsino 2008). Thus, the tendency for larger mineral-associated SOM fractions under PC might indicate an improved nutrient sorption, water-holding capacity, and soil structural and SOM stability under PC (Wander 2004; Grego and Lagomarsino 2008). According to Jackson et al. (2017), markedly larger amounts of belowground biomass (45\%) are stabilized in SOM compared to aboveground biomass (8\%) and mainly simple organic compounds undergo organo-mineral formation (Blume et al. 2016). Thus, it was assumed that the larger mineral-associated SOM fractions under PC were caused by temperature-induced larger root growth 
accompanied by larger root and microbial exudation under PC (Fernandez et al. 2001; Kumar and Dey 2011; Yin et al. 2013). Similarly, the wider C:N ratios in the 30-60$\mathrm{cm}$ soil layer under PC point to a more hardly degradable SOM (Kindler et al. 2011), which could decelerate microbial SOM mineralization and thus preserve SOM and nitrogen stocks in the subsoil (Jia et al. 2006).

The MBC:MBN ratios under PC indicate an increasing and larger fungal fraction compared to SC, pointing to a shift in microbial community (Campbell et al. 1991). At the beginning of the experiment (T0-T2), the MBC:MBN ratios indicated larger fungal fractions under bare soil compared to PC, which were attributed to aboveground biomass entry, promoting fungal growth (Meyer et al. 2020). However, during the annual fungicide application (in flowering period), the soil under SC received larger fungicide loads than under $\mathrm{PC}$, which reduced fungal growth or rather promoted bacterial growth under SC (Meyer et al. 2021). The larger soil temperature under PC might have additionally favored fungal growth (Pietikåinen et al. 2005; Drenovsky et al. 2010). The influence of PC on microbial community and potential shifts towards mycotoxigenic fungi was already discussed before (Buyer et al. 2010; Muñoz et al. 2015, 2017). However, more detailed investigations are required to verify these indications on microbial community shifts under PC, which additionally seem to vary in dependence of the pesticide treatment and the duration of the PC application.

\subsection{Influence of seasonality, time, and soil depth on coverage effects}

Several investigated soil parameters confirmed the assumption of a seasonal, time- and depth-dependent impact of soil coverage on soil parameters and processes. The differences between coverage types in soil temperature and partly in soil moisture, the main drivers of PC effects (Gan et al. 2013), exhibit strong seasonal and depth-dependent effects, which have already been observed for soil temperature by Wang et al. (2015). However, these differences were not reflected in temperature- and moisture-sensitive soil parameters such as MBC and MBN (Pietikåinen et al. 2005; Bárcenas-Moreno et al. 2009). Additionally, seasonal effects were observed to some extent also in DOC and water-stable aggregates. The influence of soil coverage was partly also observed below the topsoil layer (e.g., for soil temperature and moisture, DOC, and MBC) or only below the topsoil layer (C:N ratios) or differed between soil layers (SOC). The effects of soil coverage on pore volumes, bulk density, and MBC became only observable in the second year of the experiment, whereas the effects on SOC, MBN, and MBC:MBN ratios changed during the sampling period, indicating several co-occurring processes which compensate for and overbalance each other after a certain time. Furthermore, the restriction of the present study to 3 years of observation may hide some long-term effects that become significant only after a longer application. For example, Liu et al. (2021) showed that in particular changes in the microbial community structure were observed after 10 years of continuous plastic mulching in a semiarid climate and Sintim et al. (2021) found a higher aggregate stability in the topsoil after 4 years of continuous plastic mulching. Thus, changes in soil properties after 3 years cannot be excluded. But a longer period was beyond the scope of this study because we wanted to test the effects of the current agricultural practices in strawberry cultivation, which is mainly restricted to 2 years or 3 years before the plastic covers and plants are removed and the ridge-furrow system is renewed. In summary, these findings on seasonal, time- and depth-dependent effects of coverage types on soil pronounce their importance and recommend to include them also in future studies for a holistic process understanding.

\section{Conclusion}

The impeded rainfall infiltration under plastic mulching reduces soil moisture under temperate, humid climate, especially when no drip irrigation is applied. Thus, the positive effects of plastic mulching on plant growth and yields are mainly induced by the seasonally elevated soil temperature. Plastic mulching neither reduces leaching nor promotes (macro-)aggregate formation or stability; however, it maintains a loose and friable soil structure in surface soil $(0-5 \mathrm{~cm})$, which can improve aeration and rooting. Furthermore, it promotes SOM accumulation and shifted SOM composition to a more hardly degradable SOM, especially below the topsoil $(10-60 \mathrm{~cm})$, which can also improve soil structure, serve as a nutrient reservoir, and enhance sorption and water-holding capacity. As from the second year, straw mulch provides fresh and fast-mineralizable substrate in the topsoil $(0-10 \mathrm{~cm})$, which enhances microbial biomass and fostering larger bacterial fractions. Our study under temperate, humid climate reveals no indications of an increased microbial biomass or activity accompanied with an accelerated SOM decomposition under plastic mulching. The study revealed no significant adverse effects of the plastic coverage on the investigated soil parameters and processes and does not point to a decreased soil quality in the investigated time period. However, the partly seasonal, time- and depthdependent effects of our study emphasize the importance of including soil depth, temporal course. and season in future studies to gain a more holistic process understanding. Additionally, further research is necessary to prove our findings on a larger scale and longer time periods and to various soil and crop types. 
Supplementary Information The online version contains supplementary material available at https://doi.org/10.1007/s11368-021-03037-3.

Acknowledgements We want to thank Christof Steegmüller for providing access to the sampling site and for his expertise in strawberry cultivation; Mathilde Knott, Christian Buchmann, Kilian Kenngott, and Zacharias Steinmetz for valuable assistance during soil samplings; and Lea Bosch, Katharina Lühmann, Camilla More, and Ken Mauser for valuable assistance during sample analyses. Furthermore, we would like to thank Prof. S. Thiele-Bruhn (University of Trier) for providing the field measuring station.

Author contribution The concept of this paper was developed by Maximilian Meyer together with Prof. Dr. Gabriele Ellen Schaumann and Dr. Katherine Andrea Muñoz Sepúlveda. Maximilian Meyer planned and conducted the experimental design and all soil samplings, data evaluations, and statistics. Maximilian Meyer had support from colleagues and technical staff during soil samplings and from technical and student staff for laboratory analyses. Data interpretation and paper writing was done by Maximilian Meyer with the support of Prof. Dr. Gabriele Ellen Schaumann, Dr. Katherine Andrea Muñoz Sepúlveda, and Dr. Dörte Diehl.

Funding Open Access funding enabled and organized by Projekt DEAL. This work was supported by the Ministry for Education, Sciences, Further Education and Culture of the State of Rhineland-Palatinate (MBWWK) in the frame of the Interdisciplinary Research Group for Environmental Studies (IFG-Umwelt) of the University of Koblenz-Landau and by the research fund of the University of Koblenz-Landau.

Availability of data and material The datasets used and/or analyzed during the current study are available from the corresponding author on reasonable request.

\section{Declarations}

Competing interests The authors declare no competing interests.

Open Access This article is licensed under a Creative Commons Attribution 4.0 International License, which permits use, sharing, adaptation, distribution and reproduction in any medium or format, as long as you give appropriate credit to the original author(s) and the source, provide a link to the Creative Commons licence, and indicate if changes were made. The images or other third party material in this article are included in the article's Creative Commons licence, unless indicated otherwise in a credit line to the material. If material is not included in the article's Creative Commons licence and your intended use is not permitted by statutory regulation or exceeds the permitted use, you will need to obtain permission directly from the copyright holder. To view a copy of this licence, visit http://creativecommons.org/licenses/by/4.0/.

\section{References}

Bárcenas-Moreno G, Gómez-Brandón M, Rousk J, Bååth E (2009) Adaptation of soil microbial communities to temperature: comparison of fungi and bacteria in a laboratory experiment. Global Change Biol 15:2950-2957. https://doi.org/10.1111/j.1365-2486.2009.01882.x

Bing So H (2006) Slaking, dispersion and crust formation. In: Rattan L (ed) Encyclopedia of soil science, 2nd edn. CRC Press, Boca Raton, pp 1579-1582

Blanco-Canqui H, Lal R (2006) Aggregates: tensile strength. Encyclopedia of soil science, 2nd edn. CRC Press, New York, pp 45-48
Blume HP (2000) Handbuch der Bodenuntersuchung: Terminologie, Verfahrensvorschriften und Datenblätter; physikalische, chemische, biologische Untersuchungsverfahren; gesetzliche Regelwerke. Wiley-VCH, Weinheim

Blume HP, Brümmer GW, Fleige H et al (2016) Scheffer/Schachtschabel soil science, 1 st edn. Springer, Berlin

Bolan NS, Adriano DC, Kunhikrishnan A et al (2011) Dissolved organic matter: biogeochemistry, dynamics, and environmental significance in soils. In: Sparks DL (ed) Advances in agronomy. Academic Press, pp 1-75

Bronick CJ, Lal R (2005) Soil structure and management: a review. Geoderma 124:3-22. https://doi.org/10.1016/j.geoderma.2004. 03.005

Buchmann C, Meyer M, Schaumann GE (2015) Characterization of wet aggregate stability of soils by H-NMR relaxometry. Magn Reson Chem 53:694-703. https://doi.org/10.1002/mrc.4147

Bünemann EK, Schwenke GD, Zwieten LV (2006) Impact of agricultural inputs on soil organisms-a review. Soil Res 44:379-406. https://doi.org/10.1071/SR05125

Butenschoen O, Scheu S, Eisenhauer N (2011) Interactive effects of warming, soil humidity and plant diversity on litter decomposition and microbial activity. Soil Biol Biochem 43:1902-1907. https:// doi.org/10.1016/j.soilbio.2011.05.011

Butler J, Reeds J, Dawson S (1981) Estimating solutions of first kind integral equations with nonnegative constraints and optimal smoothing. SIAM J Numer Anal 18:381-397. https://doi.org/10. $1137 / 0718025$

Buyer JS, Teasdale JR, Roberts DP et al (2010) Factors affecting soil microbial community structure in tomato cropping systems. Soil Biol Biochem 42:831-841. https://doi.org/10.1016/j.soilbio.2010. 01.020

Cameron KC, Di HJ, Moir JL (2013) Nitrogen losses from the soil/ plant system: a review. Ann Appl Biol 162:145-173. https://doi. org/10.1111/aab.12014

Campbell CA, Biederbeck VO, Zentner RP, Lafond GP (1991) Effect of crop rotations and cultural practices on soil organic matter, microbial biomass and respiration in a thin Black Chernozem. Can J Soil Sci 71:363-376. https://doi.org/10.4141/cjss91-035

Cerli C, Celi L, Kalbitz K et al (2012) Separation of light and heavy organic matter fractions in soil - testing for proper density cut-off and dispersion level. Geoderma 170:403-416. https://doi.org/10. 1016/j.geoderma.2011.10.009

Coûteaux MM, Bottner P, Berg B (1995) Litter decomposition, climate and liter quality. Trends Ecol Evol 10:63-66. https://doi.org/10. 1016/S0169-5347(00)88978-8

Deng XP, Shan L, Zhang H, Turner NC (2006) Improving agricultural water use efficiency in arid and semiarid areas of China. Agric Water Manage 80:23-40. https://doi.org/10.1016/j.agwat.2005. 07.021

Drenovsky RE, Steenwerth KL, Jackson LE, Scow KM (2010) Land use and climatic factors structure regional patterns in soil microbial communities. Global Ecol Biogeogr 19:27-39. https://doi. org/10.1111/j.1466-8238.2009.00486.x

Farmer J, Zhang B, Jin X et al (2017) Long-term effect of plastic film mulching and fertilization on bacterial communities in a brown soil revealed by high through-put sequencing. Arch Agron Soil Sci 63:230-241. https://doi.org/10.1080/03650340. 2016.1193667

Fernandez GE, Butler LM, Louws FJ (2001) Strawberry growth and development in an annual plasticulture system. HortScience 36:1219-1223. https://doi.org/10.21273/HORTSCI.36.7.1219

Gan Y, Siddique KHM, Turner NC et al (2013) Ridge-furrow mulching systems - an innovative technique for boosting crop productivity in semiarid rain-fed environments. In: Sparks DL (ed) Advances in agronomy. Academic Press, pp 429-476 
Gao H, Yan C, Liu Q et al (2019) Exploring optimal soil mulching to enhance yield and water use efficiency in maize cropping in China: a meta-analysis. Agric Water Manage 225:105741. https:// doi.org/10.1016/j.agwat.2019.105741

Grego S, Lagomarsino A (2008) Soil organic matter in the sustainable agriculture: source or sink of carbon? In: Marinari S, Caporali S (eds). Soil carbon sequestration under organic farming in the Mediterranean environment. Transworld Research Network, Kerala, pp $39-51$

Ham JM, Kluitenberg GJ (1994) Modeling the effect of mulch opticalproperties and mulch soil contact resistance on soil heating under plastic mulch culture. Agric for Meteorol 71:403-424. https://doi. org/10.1016/0168-1923(94)90022-1

Ham JM, Kluitenberg GJ, Lamont WJ (1993) Optical properties of plastic mulches affect the field temperature regime. J Amer Soc Hort Sci 118:188-193. https://doi.org/10.21273/JASHS.118.2.188

Han J, Jia Z, Wu W et al (2014) Modeling impacts of film mulching on rainfed crop yield in Northern China with DNDC. Field Crops Res 155:202-212. https://doi.org/10.1016/j.fcr.2013.09.004

Harris D, Horwáth WR, van Kessel C (2001) Acid fumigation of soils to remove carbonates prior to total organic carbon or CARBON-13 isotopic analysis. Soil Sci Soc Am J 65:1853-1856. https://doi.org/ 10.2136/sssaj2001.1853

Haynes RJ (2005) Labile organic matter fractions as central components of the quality of agricultural soils: an overview. In: Sparks DL (ed) Advances in agronomy. Academic Press, pp 221-268

Huo L, Pang H, Zhao Y et al (2017) Buried straw layer plus plastic mulching improves soil organic carbon fractions in an arid saline soil from Northwest China. Soil Tillage Res 165:286-293. https:// doi.org/10.1016/j.still.2016.09.006

Ingman M, Santelmann MV, Tilt B (2015) Agricultural water conservation in China: plastic mulch and traditional irrigation. Ecosyst Health Sustainability 1:1-11. https://doi.org/10.1890/ EHS14-0018.1

IUSS Working Group WRB (2015) World Reference Base for Soil Resources 2014, update 2015. International soil classification system for naming soils and creating legends for soil maps. FAO, Rome

Jackson RB, Lajtha K, Crow SE et al (2017) The ecology of soil carbon: pools, vulnerabilities, and biotic and abiotic controls. Annu Rev Ecol Evol Syst 48:419-445. https://doi.org/10.1146/ annurev-ecolsys-112414-054234

Jia Y, Li FM, Wang XL, Xu JZ (2006) Dynamics of soil organic carbon and soil fertility affected by alfalfa productivity in a semiarid agro-ecosystem. Biogeochemistry 80:233-243. https://doi.org/10. 1007/s10533-006-9020-z

Joergensen RG, Brookes PC (1990) Ninhydrin-reactive nitrogen measurements of microbial biomass in $0.5 \mathrm{~m} \mathrm{~K} 2 \mathrm{SO} 4$ soil extracts. Soil Biol Biochem 22:1023-1027. https://doi.org/10.1016/00380717(90)90027-W

Kasirajan S, Ngouajio M (2012) Polyethylene and biodegradable mulches for agricultural applications: a review. Agron Sustainable Dev 32:501-529. https://doi.org/10.1007/s13593-011-0068-3

Khan AR, Chandra D, Quraishi S, Sinha RK (2000) Soil aeration under different soil surface conditions. J Agron Crop Sci 185:105-112. https://doi.org/10.1046/j.1439-037X.2000.00417.x

Kindler R, Siemens JAN, Kaiser K et al (2011) Dissolved carbon leaching from soil is a crucial component of the net ecosystem carbon balance. Global Change Biol 17:1167-1185. https://doi.org/10. 1111/j.1365-2486.2010.02282.x

Kumar S, Dey P (2011) Effects of different mulches and irrigation methods on root growth, nutrient uptake, water-use efficiency and yield of strawberry. Sci Hortic 127:318-324. https://doi.org/10. 1016/j.scienta.2010.10.023

Lal R (2006) Encyclopedia of soil science. CRC Press, New York
Le Bissonnais Y (2006) Aggregate breakdown mechanisms and erodibility. In: Rattan L (ed) Encyclopedia of soil science, 2nd edn. CRC Press, Boca Raton, pp 40-44

Li FM, Song QH, Jjemba PK, Shi YC (2004) Dynamics of soil microbial biomass $\mathrm{C}$ and soil fertility in cropland mulched with plastic film in a semiarid agro-ecosystem. Soil Biol Biochem 36:18931902. https://doi.org/10.1016/j.soilbio.2004.04.040

Li YS, Wu LH, Zhao LM et al (2007) Influence of continuous plastic film mulching on yield, water use efficiency and soil properties of rice fields under non-flooding condition. Soil Tillage Res 93:370378. https://doi.org/10.1016/j.still.2006.05.010

Liu EK, He WQ, Yan CR (2014) 'White revolution' to 'white pollution'-agricultural plastic film mulch in China. Environ Res Lett 9:091001. https://doi.org/10.1088/1748-9326/9/9/091001

Liu J, Li S, Yue S et al (2021) Soil microbial community and network changes after long-term use of plastic mulch and nitrogen fertilization on semiarid farmland. Geoderma 396:115086. https://doi. org/10.1016/j.geoderma.2021.115086

Luo S, Zhu L, Liu J et al (2015) Sensitivity of soil organic carbon stocks and fractions to soil surface mulching in semiarid farmland. Eur J Soil Biol 67:35-42. https://doi.org/10.1016/j.ejsobi.2015.01.004

Ma D, Chen L, Qu H et al (2018) Impacts of plastic film mulching on crop yields, soil water, nitrate, and organic carbon in Northwestern China: a meta-analysis. Agric Water Manage 202:166-173. https://doi.org/10.1016/j.agwat.2018.02.001

Meyer M, Buchmann C, Schaumann GE (2018) Determination of quantitative pore-size distribution of soils with $1 \mathrm{H}$ NMR relaxometry. Eur J Soil Sci 69:393-406. https://doi.org/10.1111/ejss.12548

Meyer M, Diehl D, Schaumann GE, Muñoz K (2020) Analysis of biogeochemical processes in plastic-covered soil during establishment period in strawberry cultivation. SN Appl Sci 2:1749. https://doi.org/10.1007/s42452-020-03528-x

Meyer M, Diehl D, Schaumann GE, Muñoz K (2021) Agricultural mulching and fungicides - impacts on fungal biomass, mycotoxin occurrence, and soil organic matter decomposition. Environ Sci Pollut Res. https://doi.org/10.1007/s11356-021-13280-3

Moore JM, Klose S, Tabatabai MA (2000) Soil microbial biomass carbon and nitrogen as affected by cropping systems. Biol Fertil Soils 31:200-210. https://doi.org/10.1007/s003740050646

Mordor Intelligence (2020) Agricultural films market. https://www. mordorintelligence.com/industry-reports/asia-pacific-agriculturalfilms-market. Accessed 4 Mar 2020

Muñoz K, Buchmann C, Meyer M et al (2017) Physicochemical and microbial soil quality indicators as affected by the agricultural management system in strawberry cultivation using straw or black polyethylene mulching. Appl Soil Ecol 113:36-44. https://doi.org/ 10.1016/j.apsoil.2017.01.014

Muñoz K, Schmidt-Heydt M, Stoll D et al (2015) Effect of plastic mulching on mycotoxin occurrence and mycobiome abundance in soil samples from asparagus crops. Mycotoxin Res 31:191-201. https://doi.org/10.1007/s12550-015-0231-9

Neri D, Baruzzi G, Massetani F, Faedi W (2012) Strawberry production in forced and protected culture in Europe as a response to climate change. Can J Plant Sci 92:1021-1036. https://doi.org/10.4141/ cjps2011-276

Ontl TA, Cambardella CA, Schulte LA, Kolka RK (2015) Factors influencing soil aggregation and particulate organic matter responses to bioenergy crops across a topographic gradient. Geoderma 255:1-11. https://doi.org/10.1016/j.geoderma.2015.04.016

Pietikåinen J, Pettersson M, Bååth E (2005) Comparison of temperature effects on soil respiration and bacterial and fungal growth rates. FEMS Microbiol Ecol 52:49-58. https://doi.org/10.1016/j.femsec. 2004.10.002

Poling EB (2016) An introductory guide to strawberry plasticulture. Department of horticultural science, NC State 
Ruidisch M, Kettering J, Arnhold S, Huwe B (2013) Modeling water flow in a plastic mulched ridge cultivation system on hillslopes affected by South Korean summer monsoon. Agric Water Manage 116:204-217. https://doi.org/10.1016/j.agwat.2012.07.011

Scarascia-Mugnozza G, Sica C, Russo G (2011) Plastic materials in European agriculture: actual use and perspectives. J Agric Eng 42:15-28. https://doi.org/10.4081/jae.2011.3.15

Schirmel J, Albert J, Kurtz MP, Muñoz K (2018) Plasticulture changes soil invertebrate assemblages of strawberry fields and decreases diversity and soil microbial activity. Appl Soil Ecol 124:379-393. https://doi.org/10.1016/j.apsoil.2017.11.025

Sintim HY, Bandopadhyay S, English ME et al (2021) Four years of continuous use of soil-biodegradable plastic mulch: impact on soil and groundwater quality. Geoderma 381:114665. https://doi.org/ 10.1016/j.geoderma.2020.114665

Sintim HY, Flury M (2017) Is biodegradable plastic mulch the solution to agriculture's plastic problem? Environ Sci Technol 51:10681069. https://doi.org/10.1021/acs.est.6b06042

Steinmetz Z, Wollmann C, Schaefer M et al (2016) Plastic mulching in agriculture. Trading short-term agronomic benefits for long-term soil degradation? Sci Total Environ 550:690-705. https://doi.org/ 10.1016/j.scitotenv.2016.01.153

Stockmann U, Adams MA, Crawford JW et al (2013) The knowns, known unknowns and unknowns of sequestration of soil organic carbon. Agric Ecosyst Environ 164:80-99. https://doi.org/10. 1016/j.agee.2012.10.001

Subrahmaniyan K, Kalaiselvan P, Balasubramanian TN, Zhou W (2006) Crop productivity and soil properties as affected by polyethylene film mulch and land configurations in groundnut (Arachis hypogaea L.). Arch Agron Soil Sci 52:79-103. https://doi.org/10. 1080/03650340500421786

Tarara JM (2000) Microclimate modification with plastic mulch. HortScience 35:169-180. https://doi.org/10.21273/HORTSCI. 35.2.169

Tisdall JM, Oades JM (1982) Organic matter and water-stable aggregates in soils. J Soil Sci 33:141-163. https://doi.org/10.1111/j. 1365-2389.1982.tb01755.x

Transparency Market Research (2020) Agricultural films market. https://www.transparencymarketresearch.com/agricultural-film. html. Accessed 4 Mar 2020

Vance ED, Brookes PC, Jenkinson DS (1987) An extraction method for measuring soil microbial biomass C. Soil Biol Biochem 19:703707. https://doi.org/10.1016/0038-0717(87)90052-6

von Lützow M, Kögel-Knabner I (2009) Temperature sensitivity of soil organic matter decomposition - what do we know? Biol Fertil Soils 46:1-15. https://doi.org/10.1007/s00374-009-0413-8

von Lützow M, Kögel-Knabner I, Ekschmitt K et al (2006) Stabilization of organic matter in temperate soils: mechanisms and their relevance under different soil conditions - a review. Eur J Soil Sci 57:426-445. https://doi.org/10.1111/j.1365-2389.2006.00809.x

von Lützow M, Kögel-Knabner I, Ekschmitt K et al (2007) SOM fractionation methods: relevance to functional pools and to stabilization mechanisms. Soil Biol Biochem 39:2183-2207. https://doi.org/10.1016/j.soilbio.2007.03.007

Wander M (2004) Soil organic matter fractions and their relevance to soil function. In: Magdoff F, Weil R (eds) Soil organic matter in sustainable agriculture. CRC Press, Boca Raton, pp 67-102

Wang L, Li XG, Lv J et al (2017) Continuous plastic-film mulching increases soil aggregation but decreases soil $\mathrm{pH}$ in semiarid areas of China. Soil Tillage Res 167:46-53. https://doi.org/10.1016/j. still.2016.11.004

Wang X, Li Z, Xing Y (2015) Effects of mulching and nitrogen on soil temperature, water content, nitrate- $\mathrm{N}$ content and maize yield in the Loess Plateau of China. Agric Water Manage 161:53-64. https://doi.org/10.1016/j.agwat.2015.07.019

Wang YP, Li XG, Fu T et al (2016) Multi-site assessment of the effects of plastic-film mulch on the soil organic carbon balance in semiarid areas of China. Agric for Meteorol 228-229:42-51. https:// doi.org/10.1016/j.agrformet.2016.06.016

Wang YP, Li XG, Hai L et al (2014) Film fully-mulched ridge-furrow cropping affects soil biochemical properties and maize nutrient uptake in a rainfed semi-arid environment. Soil Sci Plant Nutri 60:486-498. https://doi.org/10.1080/00380768.2014.909709

Yang Y, Yu K, Feng H (2018) Effects of straw mulching and plastic film mulching on improving soil organic carbon and nitrogen fractions, crop yield and water use efficiency in the Loess Plateau, China. Agric Water Manage 201:133-143. https://doi.org/10. 1016/j.agwat.2018.01.021

Yin H, Xiao J, Li Y et al (2013) Warming effects on root morphological and physiological traits: the potential consequences on soil $\mathrm{C}$ dynamics as altered root exudation. Agric for Meteorol 180:287-296. https://doi.org/10.1016/j.agrformet.2013.06.016

Zhang F, Zhang W, Li M et al (2017) Does long-term plastic film mulching really decrease sequestration of organic carbon in soil in the Loess Plateau? Eur J Agron 89:53-60. https://doi.org/10. 1016/j.eja.2017.06.007

Zhang F, Zhang W, Qi J, Li FM (2018) A regional evaluation of plastic film mulching for improving crop yields on the Loess Plateau of China. Agric for Meteorol 248:458-468. https://doi.org/10.1016/j. agrformet.2017.10.030

Zhang GS, Hu XB, Zhang XX, Li J (2015) Effects of plastic mulch and crop rotation on soil physical properties in rain-fed vegetable production in the mid-Yunnan plateau, China. Soil Tillage Res 145:111-117. https://doi.org/10.1016/j.still.2014.09.010

Zhao Y, Zhai X, Wang Z et al (2018) Simulation of soil water and heat flow in ridge cultivation with plastic film mulching system on the Chinese Loess Plateau. Agric Water Manage 202:99-112. https:// doi.org/10.1016/j.agwat.2018.02.017

Publisher's Note Springer Nature remains neutral with regard to jurisdictional claims in published maps and institutional affiliations. 